\title{
ANÀLISI DEL POTENCIAL DE LA CUSTÒDIA FLUVIAL A CATALUNYA I PROPOSTES D'INNOVACIÓ ${ }^{1}$
}

\author{
JORDI RECORDÀ COS \\ Ambientòleg i Màster en Dret Ambiental (URV) \\ jordirecordacos@gmail.com
}

Rebut: 3 d'octubre de 2011 / Acceptat: 17 de novembre de 2011

RESUM: La necessitat de millorar la conservació dels espais aquàtics d'aigua dolça ha obligat a superar la tradicional actuació de l'Administració, per actuar, també, en els espais naturals privats. La intervenció de nous actors com el propietari dels terrenys i la societat civil, a través de les entitats de custòdia, s'ha emmarcat en els acords de custòdia del territori.

L'actuació de la custòdia en aquests espais (la custòdia fluvial, CF) està subjecta a límits legals, com ara l'encaix amb la directiva marc de l'aigua, la determinació de l'àmbit d'actuació i de les administracions competents implicades. A Catalunya, les dades de l'últim inventari (2009) mostren que s'han realitzat 176 acords, que es desglossen en 5 tipus diferents. La protecció de gairebé 32.000 ha, tant en finques privades com públiques, posa de manifest el potencial d'aquests instruments, i la seva progressiva consolidació.

Es proposa la intervenció de la CF en els recursos hídrics, independentment de la finca on es troben, per intervenir en els cabals de manteniment i les aigües regenerades. També es planteja el cas de les aigües privades, en què les entitats de CF podrien intervenir per garantir l'ús sostenible del recurs.

RESUMEN: La necesidad de mejorar la conservación de los espacios acuáticos de agua dulce ha obligado a superar la tradicional actuación de la administración, para actuar

\footnotetext{
${ }^{1}$ Aquest article s'ha basat en el treball del mateix autor: Instruments per al desenvolupament sostenible. La custòdia del territori aplicada en els ambients aquàtics (aigua dolça), guanyador del I Premi de Recerca de la Càtedra DOW/URV de Desenvolupament Sostenible (2010).
} 
también en los espacios naturales privados. La intervención de nuevos actores como el propietario de los terrenos y la sociedad civil, a través de las entidades de custodia, se ha enmarcado en los acuerdos de custodia del territorio.

La actuación de la custodia en estos espacios (la custodia fluvial, CF) estará sujeto a unos límites legales como el encaje con la Directiva Marco del Agua, la determinación del ámbito de actuación y de las administraciones competentes implicadas. En Cataluña, los datos del último inventario (2009), muestran que se han realizado 176 acuerdos, que se desglosen en 5 tipos diferentes. La protección de casi 32.000 ha, tanto en fincas privadas como públicas, pone de manifiesto el potencial de estos instrumentos, y su progresiva consolidación.

Se propone la intervención de la CF en los recursos hídricos, independientemente de la finca donde se encuentran, para intervenir en los caudales de mantenimiento y las aguas regeneradas. También se plantea el caso de las aguas privadas, donde las entidades de CF podrían intervenir para garantizar el uso sostenible del recurso.

RESUMÉ : La nécessité d'améliorer la conservation des milieux aquatiques d'eau douce a obligé à dépasser la traditionnelle intervention de l'administration pour agir aussi sur les espaces naturels privés. L'intervention des nouveaux acteurs comme le propriétaire du terrain et la société civile, à travers les institutions de gestion conservatoire, a été formulée dans les accords de gestion.

L'intervention de la gestion conservatoire dans les milieux aquatiques sera soumise à des limites juridiques compatibles à la directive cadre sur l'eau, la détermination de la zone d'action et des autorités compétentes concernées. En Catalogne, les données du dernier inventaire (2009) montrent que 176 accords ont été conclus, qui se classifient en 5 types différents. La protection de près de 32000 hectares, sur des propriétés privées comme publiques, souligne le potentiel de ces instruments et sa consolidation progressive.

Il est proposé l'intervention de la gestion conservatoire des milieux aquatiques sur les ressources hydriques, indépendamment de la propriété où ils se trouvent, pour intervenir sur les débits réservés et les eaux recyclées. Il est aussi prévu le cas des eaux privées, pour lesquelles l'intendance du territoire pourrait intervenir pour garantir l'utilisation durable de la ressource. 
PARAULES CLAU: custòdia del territori - custòdia fluvial - espais aquàtics — aigües privades — domini públic hidràulic.

PALABRAS CLAVE: custodia del territorio - custodia fluvial — espacios acuáticos — aguas privadas — dominio público hidráulico.

MOTS CLÉS: intendance du territoire - milieux aquatiques — eaux privées domaine public fluvial.

KEYWORDS: land stewardship — stewardship of rivers — natural water areas — private water — hydraulic public domain.

Sumari: I. Introducció. II. La custòdia del territori. 1.Introducció a la custòdia del territori. 1.1. Definició de custòdia del territori. 1.2. Actors principals. 1.3. Actors secundaris. 2.Instruments de custòdia del territori. 2.1. Instruments jurídics basats en el dret privat. 2.2. Instruments jurídics basats en el dret públic. III. La custòdia del territori en els espais aquàtics: la custòdia fluvial. 1. Potencial de la directiva marc de l'aigua per aplicar la custòdia fluvial. 2. Administracions competents en la gestió dels espais aquàtics. 3. Àmbit d'actuació de la custòdia fluvial. 3.1. Tipus d' espais naturals aquàtics (aigua dolça). 3.2. Espais naturals aquàtics on es pot aplicar la custòdia fluvial. 4. Anàlisi dels acords de custòdia fluvial realitzats a Catalunya. 5. Intervenció de la custòdia fluvial sobre el recurs de l'aigua. 5.1. L'aigua: un recurs que cal custodiar. 5.2. Projectes d'innovació en custòdia fluvial. A. Garantia dels cabals de manteniment. B. Intervenció en la gestió de les aigües regenerades. IV. Límits de la custòdia. V. Consideracions finals.

\section{INTRODUCCIÓ}

L’objectiu d'aquest article és analitzar quin potencial ofereix a Catalunya la custòdia del territori per millorar la protecció dels espais naturals amb valors relacionats amb els medis aquàtics d'aigua dolça (la custòdia fluvial), i presentar noves vies per desenvolupar aquests mecanismes.

Les polítiques tradicionals de protecció dels espais naturals han estat liderades per les administracions, però els objectius de conservació de la biodiversitat no s'han aconseguit de forma plena. Es planteja, doncs, la necessitat de buscar una actuació complementària, per exemple en els espais naturals privats.

Les noves estratègies de participació ciutadana en polítiques ambientals s'apliquen, també, en la gestió dels espais naturals, i han trobat en els instruments de custòdia un 
dels seus principals estendards. Aquesta estratègia es basa en els acords entre els diferents actors implicats en la gestió del territori, i actua principalment en les finques privades, on els propietaris i les entitats de custòdia arriben a acords per conservar la biodiversitat. Tot i la complexitat d'aquests instruments, cal destacar la importància dels aspectes relacionals entre els diferents actors per generar confiança mútua i corresponsabilitat com a eixos per a un desenvolupament més durable.

En l'actual context de crisi econòmica, la custòdia del territori es presenta com un mecanisme innovador que ha generat nous llocs de treball $i$ ha contribuït a consolidar els projectes de diverses ONG, fonamenta el treball en xarxa entre organitzacions, Administració, propietaris privats i empreses, i consolida el diàleg i la comprensió entre aquests sectors que tenen un paper fonamental en la gestió de la biodiversitat, i posen en relleu el seu compromís davant el conjunt de la societat.

L'Estat espanyol encara és jove en aquesta estratègia, i la resposta del dret ambiental no aborda encara plenament aquests instruments, ja que s'ha centrat més en la intervenció de l'Administració que en la implicació dels propietaris privats a l'hora de conservar la biodiversitat. Tanmateix, ja existeix la figura dels acords voluntaris ${ }^{2}$, més utilitzats en altres sectors ambientals que en el de la conservació de la biodiversitat.

En aquest treball, estudiem el cas concret de l'aplicació d'aquests instruments en la protecció dels espais aquàtics d'aigua dolça, ja que es tracta d'espais naturals de gran valor per a la conservació, però a la vegada sotmesos a fortes pressions antròpiques que les amenacen, fins al punt de posar en perill l'assoliment dels objectius de la directiva marc de l'aigua (DMA). La custòdia aplicada als espais aquàtics s'anomena custòdia fluvial (CF), i fins ara un estudi específic del seu marc d'actuació i de l'avaluació de la seva aplicació a Catalunya havia estat inèdit.

Tradicionalment, s'ha prioritzat la intervenció en les finques privades i els acords amb els propietaris privats. En aquest article volem fer una aportació al desenvolupament de la CF estudiant com es poden realitzar acords de custòdia també amb les administracions públiques, i si es pot superar l'actuació en les finques per actuar directament sobre els recursos naturals, com ara l'aigua. Aquest nou pas es justifica

\footnotetext{
${ }^{2}$ Per a més informació sobre la utilització de la figura dels "acords voluntaris" en la gestió dels espais naturals, i la diferència respecte dels instruments de custòdia, consulteu PALLARÈS SERRANO, A., "El recurs a la custòdia del territori i als acords voluntaris en l'àmbit del patrimoni natural i la biodiversitat", a Revista catalana de dret públic, núm. 41, 2010.
} 
perquè es pot donar el cas que les aigües no siguin del mateix propietari de la finca on es troben, i que, per tant, la custòdia de la finca no sigui suficient per garantir la protecció del recurs. Aquest podria ser el cas de les aigües privades. Es planteja, doncs, la necessitat d'actuar directament sobre l'aigua, independentment de la finca, per protegir la bona conservació dels recursos hídrics.

El treball es divideix en tres grans apartats. El primer és més introductori i permet aproximar-se a les característiques de la custòdia del territori. El segon apartat entra a debatre les qüestions plantejades sobre la CF i presenta actuacions innovadores, i, finalment, el tercer apartat se centra en els límits d'aquests mecanismes de la custòdia.

\section{LA CUSTÒDIA DEL TERRITORI}

\section{Introducció a la custòdia del territori}

\subsection{Definició de custòdia del territori}

La custòdia del territori ${ }^{3}$ és un conjunt d'estratègies $i$ instruments que pretenen establir acords i vies de col·laboració entre diferents agents públics i privats, amb l'objectiu de conservar els valors naturals, culturals i paisatgístics del territori i promoure l'ús responsable dels recursos ${ }^{4}$.

Aquest instrument posa de manifest la necessitat d'ampliar l'actuació tradicional de les polítiques públiques sobre protecció i gestió dels espais naturals per actuar en la protecció i gestió dels valors ambientals i culturals de les finques privades. La necessitat d'arribar a un acord voluntari amb el propietari, per compaginar l'ús de la terra amb la conservació dels valors de la finca, és l'eix de la custòdia del territori.

\footnotetext{
3 Sobre l'origen de la custòdia del territori en l'àmbit internacional i a Espanya, vegeu GÓMEZ GONZÁLEZ, JM.,"La Custodia del Territorio como instrumento social en la conservación del patrimonio natural", en Revista Ecosostenible, núm. 16, 2006, pp. 37-43. Sobre l'evolució històrica a Espanya de la custòdia del territorio, vegeu també ALVAREZ CARREÑO, S.M., HERNÁNDEZ LÓPEZ, S.M., "La Custódia del Territorio como instrumento complementario para la protección de espacios naturales", a Revista Catalana de Dret Ambiental, núm. 1 Vol. II, 2011, pp.4-7.

${ }^{4}$ Aquesta és la definició de custòdia que presenta la Xarxa de Custòdia del Territori (XCT). Vegeu BASORA, X.; GORDI, J.; SABATÉ, X.; VICENTE, E., Oportunitats per la custòdia del territori als municipis. Guia pràctica per a ajuntaments $i$ entitats locals, FTP-OSCC, XCT, Barcelona, 2005, p. 9. Fins ara han aparegut altres definicions, ja que es tracta d'un concepte obert i en continua evolució. Des del punt de vista jurídic, la Llei 42/2007, de 13 de desembre, del patrimoni natural i la biodiversitat (BOE núm. 299, de 14/12/2007), proposa la definició: "conjunt d'estratègies o tècniques jurídiques a través de les quals s'impliquen els propietaris i usuaris del territori en la conservació i ús del valors i els recursos naturals, culturals i paisatgístics" (art. 3.9).
} 
La custòdia no només té l'objectiu de tenir cura del medi ambient (guardar-lo, conservar-lo, respectar-lo), entenent-lo com un bé jurídic en un sentit restrictiu (els recursos naturals), sinó que pren un sentit més ampli i inclou, també, el patrimoni cultural $^{5}$. Segurament, per evitar autolimitar-se, el mateix concepte pren el nom de custòdia del territori i no custòdia del medi ambient, entenent per territori tant els elements naturals com el patrimoni cultural.

En definitiva, la custòdia ofereix uns serveis ambientals que beneficien el conjunt de la societat, i consolida estratègies per a un desenvolupament sostenible i respectuós amb l'entorn.

\subsection{Actors principals}

El concepte de la custòdia del territori es basa en la necessitat d'involucrar els diferents actors que participen en la gestió del territori. És a dir, té la finalitat de conjugar part dels seus interessos per acordar una gestió comuna i efectiva que protegeixi els valors ambientals i culturals d'un espai concret.

D'una banda, un dels actors és l'Administració ${ }^{6}$, com a garant de la protecció de l'interès general que és la protecció del medi ambient (art. 45.2 de la Constitució espanyola, d'ara endavant CE), acció que inclou la conservació de la biodiversitat ${ }^{7}$. Per exemple, les administracions locals tenen un rol molt destacat gràcies a la seva proximitat amb els propietaris i amb els usuaris del territori.

La custòdia és una eina innovadora en el panorama tradicional de les polítiques ambientals perquè no condiciona la major part de la responsabilitat a l'actuació de l'Administració, sinó que corresponsabilitza la societat civil en el deure de la protecció

\footnotetext{
${ }^{5}$ Sobre el concepte de medi ambient, es planteja un sentit restrictiu (només recursos naturals fonamentals per la vida humana), ampli (el conjunt de relacions socioeconòmiques que afecten la persona) o intermedi (deixant de banda territori i urbanisme), tal com es tracta a BLANCO LOZANO, C., Tratado de Derecho Penal Español, Volum II, Bosch, Barcelona, 2005, pp. 230-238.

${ }^{6}$ Cal puntualitzar que les administracions poden exercir diferents rols: actuar com a propietaris, en el cas que siguin titulars de la finca, com a entitats de custòdia amb capacitat per establir acords, o bé donar suport a iniciatives de custòdia com a node d'expertesa. Vid in totum BASORA, X., GORDI, J.; SABATÉ, X.; VICENTE, E.; op. cit.; p. 1-65. Vegeu també BARREIRA, A. (coord.) [et al.] Estudio jurídico sobre la custodia del territorio. Plataforma de Custodia del Territorio de la Fundación Biodiversidad, 2010, pp.154-156.

${ }^{7}$ Vegeu l'article 1 de la Llei 42/2007 : “Aquesta Llei estableix el règim jurídic bàsic de la conservació, ús sostenible, millora i restauració del patrimoni natural i de la biodiversitat, com a part del deure de conservar i del deure a gaudir d'un medi ambient adequat pel desenvolupament de la persona, establert en l'art.45.2 de la Constitució."
} 
del medi ambient. Aquesta opció es reforça en la mateixa CE quan en l'article 45, en l' apartat 2, afirma "Els poders públics han de vetllar per la utilització racional de tots els recursos naturals (...) amb el suport de la indispensable solidaritat col·lectiva." El segon actor és, doncs, la societat civil, que canalitza la seva acció a través de les "entitats de custòdia", que són organitzacions públiques o privades sense afany de lucre, que participen activament en la conservació del territori mitjançant tècniques de custòdia del territori" ${ }^{\prime}$. A la tasca de les entitats hi donen suport diferents xarxes que ajuden a crear sinèrgies. És el cas de la Xarxa de Custòdia del Territori (XCT, Catalunya), Iniciativa per la Custòdia del Territori a les Illes Balears (ICTIB), Associació Valenciana de Custòdia i Gestió Responsable del Territori, etc.

El tercer actor és el propietari de la finca. Aquest és un element definitori de l'acció de custodiar, ja que bona part dels elements naturals i culturals que cal conservar es troben en finques privades.

\subsection{Actors secundaris}

Els actors secundaris no participen directament en tots els acords de custòdia però donen suport a diferents iniciatives de custòdia.

Cal destacar els anomenats "nodes d'expertesa", que tenen per objectiu donar suport a les iniciatives de custòdia (expertesa legal, tècnica, financera o institucional), i que estan constituïts per empreses (consultories ambientals...), ONG de serveis, professionals qualificats i cooperatives que són membres de l'XCT.

Un altre actor, més secundari però que va prenent força, és el sector empresarial, que s'implica en la millora de la biodiversitat $i$, per exemple, finança actuacions de conservació de finques custodiades. És el cas de les jornades de responsabilitat social corporativa, en què les empreses col·laboren en la recuperació del bosc de ribera amb plantacions de vegetació autòctona ${ }^{9}$.

\footnotetext{
${ }^{8}$ Aquesta definició és la que ofereix la Xarxa de Custòdia del Territori, tot i que n'existeixen d'altres. Cal tenir en compte que en el cas de les entitats de custòdia públiques (ajuntaments, diputacions...) no es pot parlar pròpiament d'un segon actor (societat civil), sinó que la seva funció de protecció del medi ambient, en aplicació de l'article $45 \mathrm{CE}$, s'ha d'equiparar al de les obligacions com a Administració (primer actor).

9 Una de les ONG conservacionistes catalanes que més treballa amb el voluntariat corporatiu és Accionatura (www.accionatura.org). L'any 2009 va realitzar 12 jornades de voluntariat amb empreses amb un total de 350 participants. Els ingressos obtinguts per aquest servei suposen al voltant d'un $4 \%$ del pressupost total d'Accionatura, cosa que consolida una nova font per diversificar el finançament de la
} 
Per acabar, caldria destacar el paper dels voluntaris ${ }^{10}$, que, amb la seva implicació desinteressada, contribueixen a fer créixer la custòdia i arrelar-la en el territori.

\section{Instruments de custòdia del territori}

\subsection{Instruments jurídics basats en el dret privat}

El principal instrument que utilitzen les entitats per dur a terme la custòdia del territori són els acords de custòdia: un conjunt de compromisos i pautes de col·laboració a mitjà i llarg termini que assumeixen tant l'entitat com el propietari dels terrenys. Aquests acords es basen en el principi de voluntarietat, és a dir, les parts hi accedeixen sense imposició $^{11}$.

Els acords solen implicar un propietari i una entitat, tot i que hi poden participar més d'un dels actors esmentats. Cada acord és particular als objectius fixats per la finca que cal custodiar, i és recomanable establir un sistema per fer-ne el seguiment ${ }^{12}$.

Els principals tipus d'acords ${ }^{13}$ són els següents:

ONG (dades facilitades per la mateixa ONG). A part, ha consolidat "El consell d'empreses per la natura", en la qual diferents empreses aporten criteris i finançament per a la millora dels projectes d'aquesta entitat. També permet descomptes d'empreses col-laboradores als seus socis i voluntaris. Per a més informació sobre la relació entre entitats de custòdia i empreses, vegeu OLLICH, M.; PARRA, C., Seminari empresa $i$ Territori. Conclusions. Document ocasional de la Xarxa de Custòdia del Territori núm. 16, XCT, Vic, 2006. Vegeu també XARXA DE CUSTÒDIA DEL TERRITORI, MEDIA RESPONSABLE (2010). Guia de bones pràctiques de RSE $i$ Custòdia del Territori. [Recuperat el 9/6/2011 de <http://www.xct.cat/mm/GUIA\%20BONES\%20PRACTIQUES_definitiva.pdf $>$ ].

${ }^{10}$ Per a més informació de projectes de voluntariat ambiental en rius, vegeu: WWF (2007). Guía para el diseño y ejecución de programas de voluntariado ambiental en ríos y riberas. [Recuperat el 15 de juny de 2011 de:

http://www.marm.gob.es/es/agua/publicaciones/Guia_para_el_disenio_y_ejecucion_de_programas_de_vo luntariado_tcm7-10387.pdf $>$ ].

${ }^{11}$ BASORA, X.; SABATÉ, X. Custodia de territorio en la práctica. Manual de introducción a una nueva estrategia participativa de conservación de la naturaleza y el paisaje, FTP-OSCC, XCT, Barcelona, 2006, p. 26-30.

${ }^{12}$ Els acords de custòdia solen preveure visites periòdiques (amb un mínim d'una anual), en les quals l'entitat i el propietari comproven el desplegament correcte dels compromisos de l'acord, i que aquests estiguin contribuint en el bon estat de conservació de la finca. Actualment, la Xarxa de Custòdia del Territori està treballant per elaborar un protocol de seguiment dels acords que ha d'estar a disposició de les entitats de custòdia. Per a més informació, vegeu: ASENSIO, N.; COLLADO, H. Protocol de seguiment $i$ avaluació d'acords per a entitats de custòdia del territori. Document ocasional de la Xarxa de Custòdia del Territori, 16, Xarxa de Custòdia del Territori,Vic, 2007.

${ }^{13}$ Vid. ASENSIO, N., CORTINA, A., PIETX, J., COLLADO, H., Opcions de custòdia del territori per a finques privades. Una guia per a la propietat, 2a edició, FTP-OSCC, XCT,Vic, 2005. Vegeu també BARREIRA, A. (coord.) [et al.]; op. cit.; pp.166-211. 
1- Acords en els quals el propietari manté la gestió de la finca, però assumeix compromisos de conservació. Les opcions jurídiques d'aquesta opció són l'acord verbal i el contracte de custòdia del territori (escrit).

2- Acords en els quals es transfereix la gestió de la finca a l'entitat. Les opcions jurídiques, basades en el dret privat, són els acords de gestió, els drets reals vinculats a la conservació (la servitud, l'usdefruit i els drets reals d'aprofitament parcial), l'arrendament de serveis i mandat, l'arrendament de drets de tala, pastura i altres drets, la cessió d'ús i l'arrendament (la cessió d'ús per a temps determinat, l'arrendament, els contractes de conreu), i la fidúcia.

3- Acords que impliquen la transmissió de la propietat a l'entitat. Les opcions jurídiques, basades en el dret privat, són la compravenda, la donació, les herències o els llegats i les permutes .

La relació de col·laboració que estableixen els acords de custòdia preveuen que les entitats de custòdia assessorin el propietari en temes tècnics i jurídics. En els casos en què el propietari transfereix la gestió de la finca o la propietat de la finca a l'entitat (durant el temps i les condicions establertes voluntàriament), aquesta ha de fer un pas més i ha d'establir les directrius de gestió, i si cal ha de redactar el pla de gestió de la finca.

\subsection{Instruments jurídics basats en el dret públic}

Les fórmules del dret públic es basen en el desplegament de la normativa administrativa, en aquest cas ambiental. Sense la pretensió d'analitzar les normatives que esmentem a continuació, analitzem el potencial que ofereixen per desenvolupar la custòdia del territori.

En l'àmbit català, la custòdia troba un fonament per desplegar-se en la legislació sectorial que promou la creació de reserves privades on es poden conservar els seus valors ambientals. És el cas de la Llei catalana 12/1985, de 13 de juny, d'espais naturals $^{14}$, que preveu que els propietaris, les associacions, les entitats locals puguin

\footnotetext{
${ }^{14}$ DOGC. núm. 556, de 28/06/1985. Més de 25 anys després, aquesta normativa encara és la vigent en matèria de protecció d'espais naturals, ja que encara no s'ha aprovat la nova llei catalana de patrimoni natural i biodiversitat, que hauria de substituir i ampliar els continguts de la Llei 12/1985, i introduir de forma específica la regulació de la custòdia del territori. L'avantprojecte de la llei es va presentar al maig
} 
promoure la declaració de "reserves naturals" a espais d'extensió reduïda amb un interès científic destacable $^{15}$, i la gestió dels espais declarats ${ }^{16}$. D'altra banda, el Decret legislatiu 2/2008, de 15 d'abril, pel qual s'aprova el Text refós de la llei de protecció del $\operatorname{animals}^{17}$, preveu que una finca privada es declari "refugi de fauna salvatge" i quedi salvaguardada de la caça ${ }^{18}$.

Cal destacar, que la primera menció específica sobre la custòdia es troba en la normativa catalana sobre l'ordenació del paisatge. La Llei $8 / 2005$, de 8 de juny, de protecció, gestió i ordenació del paisatge ${ }^{19}$, incorpora en l'article 15.3, l'obligació de l'Administració de potenciar la custòdia del territori com una eina per protegir el paisatge. Tanmateix, no especifica com s'ha de dur a terme aquesta promoció.

També hem de destacar la Llei 22/2009, de 23 de desembre, d'ordenació sostenible de la pesca en aigües continentals ${ }^{20}$, que ofereix possibilitats per promoure la custòdia. Per exemple, es podria introduir el concepte de la custòdia en la formació prevista en els plans i programes de formació en el respecte dels ecosistemes aquàtics continentals, i en el programa de formació de les escoles del riu. En aquest sentit, les entitats de custòdia tenen la consideració de col·laboradors preferents per dur a terme les funcions formatives esmentades ${ }^{21}$.

La llei d'ordenació sostenible de la pesca obre les portes a la participació ciutadana en la conservació i recuperació dels ecosistemes aquàtics continentals a partir de la figura de les entitats tutores de la pesca $\mathrm{i}$ de les entitats tutores del $\mathrm{riu}^{22}$. Les entitats de custòdia del territori tenen aquesta consideració i poden exercir la seva actuació en els trams que tinguin assignats.

de 2010. L'XCT ha presentat al·legacions, especialment en els capítols referents a la custòdia del territori $\mathrm{i}$ als instruments, fiscals i financers. Podeu consultar aquest document a :

$<$ http://www.xct.cat/mm/file/100526_al\%C2\%B7legacions_xct_avantprojecte_llei_biodiversitat.pdf $>$.

15 Art. 27.1.b.

16 Art. 29.1.b.

17 DOGC núm. 5113, de 17/04/2008.

18 Art. 37 de la Llei 3/1988.

19 DOGC núm. 4407, de 16/06/2005.

20 DOGC núm. 5536, 30/12/2009.

21 Art. 48 de la Llei 22/2009.

22 Art. 49 de la Llei 22/2009. 
En l'àmbit estatal, cal destacar la Llei $42 / 2007^{23}$; és la primera normativa estatal que esmenta directament la custòdia del territori, i posa les bases per promoure-la com un instrument complementari de gestió d'espais naturals.

La llei amplia els instruments de conservació protecció dels espais naturals, com els plans de gestió i les mesures reglamentaries, cap a nous instruments com la custòdia del territori que desplega en el títol $\mathrm{V}^{24}$.

Una de les novetats de la Llei 42/2007 és la possibilitat que les entitats de custòdia es puguin beneficiar d'un règim jurídic que permeti a aquestes organitzacions obtenir fons públics (Fons pel Patrimoni Natural i la Biodiversitat) ${ }^{25}$ per establir acords de custòdia, tot i que no deixa clar si l'àmbit de l'actuació de les entitats ha de ser estatal (desenvolupar actuacions que afectin més d'una comunitat autònoma) ${ }^{26}$.

Segons aquesta llei, el rol de l'Administració no ha de ser passiu sinó que ha de promoure de manera específica la custòdia del territori ${ }^{27}$, fins $\mathrm{i}$ tot quan els terrenys siguin de domini públic ${ }^{28}$.

Tanmateix, l'esmentada llei no desplega amb profunditat el règim jurídic de la custòdia, no promou els incentius per als propietaris privats i limita l'actuació dels municipis, ja que no poden intervenir en la declaració d'espais naturals protegits, tot i que els pugui afectar directament competències pròpies com la planificació urbanística.

El mateix any s'aprovà la Llei 45/2007, de 13 de desembre, per al desenvolupament sostenible del medi rural ${ }^{29}$, que obre les portes a utilitzar els instruments de custòdia, ja que estableix com un dels seus objectius "conservar i recuperar el patrimoni i les

\footnotetext{
${ }^{23}$ Aquesta llei deroga la Llei estatal 4/1989, de 27 de març, de conservació dels espais naturals i de la flora i fauna silvestres. En aquesta normativa, en la disposició addicional 6a, l'Estat preveia la concessió d'ajudes a les ONG tant per adquirir terrenys, com per establir drets reals amb finalitats conservacionistes. Tot i que no parla directament de custòdia, sí que fa referència als seus mecanismes habituals.

${ }^{24}$ Foment del coneixement, la conservació i restauració del patrimoni natural i la biodiversitat. Art. del 71 al 74 de la Llei $42 / 2007$.

${ }^{25}$ Art.74.2, apartat m) de la Llei 42/2007. Aquest article determina que el funcionament del Fons es regula per reial decret, prèvia consulta a les comunitats autònomes, però de moment encara no s'ha aprovat.

${ }^{26}$ A part dels fons públics, la llei també preveu el finançament de les entitats de custòdia a partir d'ajuts del Ministeri de Medi Ambient i Medi Rural i Marí que, en aquest cas, sí que estan específicament condicionats a una actuació en l'àmbit estatal. Art. 71 de la Llei 42/2007.

${ }^{27}$ Art. 72.1 de la Llei 42/2007.

${ }^{28}$ Art. 72.2 de la Llei 42/2007.

${ }^{29}$ BOE núm. 299, de 14/12/2009.
} 
recursos naturals i culturals del medi rural a través d'actuacions públiques i privades que permetin la seva utilització compatible amb un desenvolupament sostenible",30. A més, els acords de custòdia realitzats en zones rurals prioritàries (per exemple, les incloses en la xarxa Natura 2000), poden rebre ajuts provinents dels Incentius Econòmics Regionals ${ }^{31}$.

\section{LA CUSTÒDIA DEL TERRITORI EN ELS ESPAIS AQUÀTICS: LA CUSTÒDIA FLUVIAL}

La baixa qualitat ecològica general dels rius catalans ${ }^{32}$ ha motivat una important sensibilització ciutadana envers els rius, com es desprèn de la destacada participació ciutadana en els projectes ambientals en l'àmbit fluvial ${ }^{33}$.

Fruit d'aquesta preocupació social, es va constituir un grup específic de custòdia fluvial (CF) en la VI Reunió de l'XCT, que va tenir lloc al Lluçanès durant l'octubre de 2009. El nou grup de custòdia ha delimitat el seu àmbit d'actuació en els següents espais:

-Ecosistemes fluvials: rius, rieres, rierols, torrents, rials, rases, rambles, barrancs, illes, galatxos, riberes, etc.

-Llacs o estanys, basses, tolls, ullals, aiguamolls, estuaris, canals i altres aigües.

L'activitat d'aquest grup ha de respectar el marc jurídic que afecta els espais aquàtics $\mathrm{i}$ ha d'adaptar els instruments de custòdia a les especificitats d'aquests espais.

\footnotetext{
${ }^{30}$ Art. 2.1. apartat c) de la Llei 45/2007.

${ }^{31}$ Art. 17.1.de la Llei 45/2007.

${ }^{32}$ Segons el Programa de Seguiment i Control de les Masses d'Aigua Catalanes, presentat per l'ACA i un grup d'experts del Departament d'Ecologia de la Universitat de Barcelona, conclou que "més de la meitat de les masses d'aigua a Catalunya (rius, llacs, aiguamolls i costa) es troba en un estat ecològic inferior a bo, i per tant, es necessiten mesures de restauració per restablir el bon estat de les masses d'aigua". Per a més informació, consulteu: <http://www.ub.edu/web/ub/ca/menu_eines/noticies/2010/10/46.html>.

${ }^{33}$ En aquest àmbit destaca l'Associació Hàbitats, que duu a terme el Projecte Rius. Segons dades de la mateixa entitat, en gairebé 15 anys de trajectòria, han aconseguit fer participar uns 900 grups de voluntaris en la inspecció dels rius catalans, i cobrir la major part de les conques catalanes. Aquesta iniciativa de voluntariat ambiental és de les més importants de Catalunya, com ho demostren els diferents reconeixements obtinguts: Premi Nacional de Voluntariat (2000 i 2009) i Premi Medi Ambient (2006), entre d'altres.
} 


\section{Potencial de la directiva marc de l'aigua per aplicar la custòdia fluvial}

Tota política o actuació de conservació dels valors naturals, culturals i paisatgístics en espais aquàtics s'ha de sotmetre als principis $\mathrm{i}$ a les directrius de la directiva marc de l'aigua (DMA) ${ }^{34}$ :

- Principi de no-deteriorament i manteniment del bon estat de les masses d'aigua superficials i subterrànies.

- Principi d'enfocament combinat de la contaminació i gestió integrada del recurs.

- Principi de participació social i transparència en les polítiques de l'aigua.

- Principi de plena recuperació de costos en la gestió dels recursos i dels espais aquàtics.

L'anàlisi d'aquests principis ha de permetre desgranar unes característiques essencials de la $\mathrm{DMA}^{35}$, que poden actuar com a punt d'ancoratge per introduir els mecanismes de la custòdia ${ }^{36}$. D'aquesta manera, s'obren noves vies per millorar la gestió i conservació dels espais aquàtics de la conca hidrogràfica.

A continuació, presentem una reflexió dels possibles temes que poden abordar tant la DMA com la $\mathrm{CF}$, i que pren com a punt de partida l'obra publicada per l'Agència Catalana de l'Aigua (ACA) Confluint en la cura de l'aigua. Reflexions sobre l'encaix entre la custòdia del territori i la DMA a Catalunya ${ }^{37}$ :

\footnotetext{
${ }^{34}$ La Directiva 2000/60/CE del Parlament i del Consell, de 23 d'octubre de 2000, per la qual s'estableix el marc comunitari d'acció en l'àmbit de la política d'aigües, coneguda com la directiva marc de l'aigua. DOUE L núm. 327, de 22 de desembre de 2000.

${ }^{35}$ Per a més informació sobre els aspectes essencials de la DMA i sobre les repercussions de la seva aplicació en l'ordenament jurídic espanyol, vegeu CASADO CASADO, L., "Principales repercusiones de la directiva marco de aguas en el ordenamiento jurídico español", a GONZÁLEZ-VARAS IBÁÑEZ, S. (coord.). Nuevo Derecho de Aguas, Civitas, Madrid, 2007, pp. 157-198; CARO-PATÓN CARMONA, I., "La Directiva Marco de aguas y su transposición al Derecho español: análisis jurídico general", en Revista Aranzadi de Derecho Ambiental, núm. 9, 2006, pp. 37-57; Vid. in totutm AGUDO GONZÁLEZ, J. (coord.), El Derecho de aguas en clave europea, La Ley, Madrid, 2010.

${ }^{36}$ Tot i que l'àmbit d'actuació de la DMA també inclou espais naturals d'aigua salada, en aquest treball es planteja la reflexió d'acord amb la CF i, per tant, es limita l'anàlisi als espais aquàtics d'aigua dolça. La protecció dels espais naturals d'aigua salada són l'objecte d'una altra branca de la custòdia: la custòdia marina.

${ }^{37}$ Vid. SABATÉ, X; BASORA, X; ROMERO-LENGUA, J., Confluint en la cura de l'aigua. Reflexions sobre l'encaix entre la custòdia del territori i la Directiva marc de l'aigua a Catalunya, Agència Catalana de l'Aigua, Barcelona, 2008.
} 
a) Aigua com a element patrimonial. L'aigua deixa de ser considerada només com un recurs per a l'explotació econòmica, i ho és com un patrimoni que s'ha de protegir, defensar i tractar com un element fonamental dels ecosistemes aquàtics.

- La protecció sobre l'aigua es pot plantejar com una actuació directa al recurs, o bé indirectament protegint l'espai on es troba. Aquesta última estratègia ha estat l'actuació tradicional de la custòdia, tot i que, en aquest treball plantegem fer un pas més, i reflexionem sobre la incidència directa de la CF en el recurs de l'aigua, independentment de la finca on es troba.

- En el cas del patrimoni cultural associat als espais aquàtics, com podrien ser pous, assuts i canals de regadiu, fàbriques tèxtils, fonts, molins, etc., seria la custòdia la que oferiria més possibilitats, ja que la DMA se centra més en els objectius de bon estat de les masses d'aigua i no-deteriorament.

b) Bon estat de les masses d'aigua. L'objectiu central de la DMA és ambiciós, ja que obliga els estats membres a assolir un "bon estat ${ }^{38}$ " de les masses d'aigua a finals del 2015 (en funció dels indicadors establerts en l'annex V de la DMA), i dóna llibertat als estats membres per aplicar les mesures que considerin adequades atenent les seves especificitats ambientals (clima, situació geogràfica) i administratives.

- L'acció de la CF per a una gestió sostenible dels espais aquàtics contribueix a la millora de les masses d'aigua. D'altra banda, la lluita contra la contaminació de les aigües no entra directament en l'àmbit de la CF.

c) Àmbit de conca hidrogràfica. La DMA potencia la visió global del cicle de l'aigua. Pren com a unitat geogràfica funcional la conca hidrogràfica, àmbit en el qual s'han d'assolir els objectius de la DMA (art. 4), i obliga els estats membres a delimitar les demarcacions hidrogràfiques i crear organismes de gestió de conca.

- La CF contribueix a la visió global del cicle de l'aigua, ja que no restringeix les accions de millora de les masses d'aigua a l'espai de domini públic hidràulic, sinó a fer-la extensiva al conjunt de la conca hidrogràfica. Per exemple, actuant

\footnotetext{
${ }^{38}$ Els objectius mínims d'estat ecològic que els estats membres hauran d'assolir abans del 22 de desembre del 2015 són els següents:

- les aigües superficials hauran de gaudir d'un "bon estat ecològic i químic";

- les aigües subterrànies hauran d'assolir un "bon estat químic i quantitatiu” per als diferents usos;

-pel que fa al medi marí, caldrà que compleixin els objectius de prevenció i eliminació de la contaminació previstos en els convenis internacionals subscrits per la UE (art. 4 i annex II).
} 
en les finques privades o públiques contigües als rius, zones humides..., per garantir una gestió coherent amb els objectius de la DMA.

- En aquest sentit, una limitació de la CF és que l'àmbit d'acció de les entitats sol ser més local, i que rarament poden abastar un àmbit tan gran com el de conca hidrogràfica.

d) Participació ciutadana: la DMA té en compte, també, l'àmbit social, ja que obliga que els instruments per assolir els objectius de la directiva (els programes de mesura i els plans de conca) incorporin la participació ciutadana.

- La CF representa un mecanisme de participació activa, ja que implica directament els ciutadans a través de les entitats de custòdia. Aquesta participació permet fer un pas més sobre l'acció més comuna de participació, basada en l'accés a la informació o la consulta.

e) Ús de l'aigua. La DMA racionalitza l'ús de l'aigua a través d'una política de preus que integra els costos totals ambientals i dels serveis associats (principi "qui contamina paga").

- Fins ara el tema de l'ús sostenible de l'aigua ha estat al centre de polítiques de sensibilització ambiental, i no tant d'estratègies de conservació de valors naturals, patrimonials i paisatgístiques.

- En canvi, s'intueix que hi ha la possibilitat d'introduir la CF en els usos privatius de l'aigua a partir de les concessions administratives.

f) Àmbits d'aplicació. Per a cada demarcació hidrogràfica, la DMA estableix categories de massa d'aigua: $i$ ) massa d'aigua superficials (rius, llacs — i zones humides—, aigües de transició, aigües costaneres); ii) massa d'aigua superficial (aigües fortament modificades i aigües artificials); iii) massa d'aigua subterrànies (aigua subterrània).

- De tots aquests àmbits, el que ofereix un encaix millor entre la CF i la DMA és el d'aigües superficials.

Un cas que cal estudiar amb més detall és el de les aigües fortament modificades, ja que podem caure en l'error de considerar que no presenten valors que s'han de conservar. És el cas de la conca del Besòs, una de les més degradades de Catalunya. L'esforç del Consorci per a la Defensa de la Conca del Besòs, de l'ACA i dels ajuntaments situats a la seva riba està posant en marxa 
projectes de millora fluvial que posen de manifest el potencial ecològic d'aquests espais; i si hi ha un bon pla de comunicació, la resposta ciutadana també és molt positiva, la qual passa d'una situació de rebuig (viure d'esquenes al riu) al gaudi d'un espai natural en vies de recuperació.

En el cas de les aigües costaneres, és un àmbit que quedaria fora de la CF perquè és objecte de treball d'un altre grup de custòdia del territori: la custòdia marina.

Una darrera reflexió de l'encaix de la $\mathrm{CF}$ amb la DMA és sobre un dels caràcters definitoris de la custòdia: la voluntarietat dels acords de custòdia, ja que no es pot garantir una actuació a llarg termini que consolidi una gestió coherent per assolir els objectius de la DMA.

\section{Administracions competents en la gestió dels espais aquàtics}

El repartiment de competències en matèria d'aigües segueix el criteri de la conca hidrogràfica, unitat geogràfica que s'utilitza per delimitar les competències estatals i autonòmiques en aquest àmbit ${ }^{39}$. Segons aquest criteri, la distribució de competències canvia segons si les conques estan dins d'una comunitat autònoma (dites intracomunitàries), en aquest cas és gestionada per la mateixa comunitat autònoma, o si són compartides entre diverses autonomies (dites intercomunitàries), que són competència de l'Estat ${ }^{40}$.

\footnotetext{
${ }^{39}$ Art. 16 del Reial decret legislatiu 1/2001, de 20 de juliol, pel qual s'aprova el Text refós de la llei d'aigües (TRLA). BOE núm. 176, de 24/07/2001: “A los efectos de la presente Ley, se entiende por cuenca hidrográfica el territorio en que las aguas fluyen al mar a través de una red de cauces secundarios que convergen en un cauce principal único. La cuenca hidrográfica, como unidad de gestión del recurso, se considera indivisible."

${ }^{40} \mathrm{El}$ tema d'aigües, tot $\mathrm{i}$ emmarcar-se com a tema ambiental, es regula per una distribució competencial especifica, sense perjudici de la incidència del títol competencial de protecció del medi ambient, i resol la discrepància de criteris constitucionals entre els articles 148.1.10 i 149.1.22, pel criteri territorial de la conca hidrogràfica declarat conforme a la CE per la STC 227/1988 del TC, i més recentment per les STC 30/2011, 32/2011 i 110/2011. Aquest criteri de distribució competencial és present des de la Llei 29/1985, de 2 d'agost, d'aigües. Per a més informació, vegeu HÉRRAEZ VILAS, P., VICENS PEDRET, X., Derecho de aguas para los Entes locales, Bayer Hermanos, Barcelona, 2010, pp. 79-82. La situació que $\mathrm{s}$ 'ha descrit també depèn del pronunciament del $\mathrm{TC}$ respecte les reformes estatutàries de diverses autonomies iniciades el 2006 que han generat tensions sobre el repartiment de competències en matèria d'aigües, com és el cas d'Andalusia, Castella-Lleó o Aragó, entre d'altres. Sobre aquest tema vegeu EMBID IRUJO, A.," Los nuevos Estatutos de Autonomia y el reparto de competencias sobre el agua y las obras hidráulicas entre el Estado y las Comunidades Autónomas", en EMBID IRUJO, A. (coord.), Agua y territorio (Consideración especial de los Estatutos de Autonomia), Civitas, Madrid, 2007; GONZÁLEZ PASCUAL, M., "Las competencias estatutarias sobre aguas: las cuencas hidrográficas como criterio competencial (Comentario a las Sentencias 32/2011 y 30/2011 del Tribunal Contitucional)", en Revista Aranzadi de derecho ambiental, n. 20, 2011, pp. 119-126; MORILLO-VELARDE PÉREZ, J.L., "La
} 
Les autoritzacions, les declaracions responsables i les concessions referents al domini públic hidràulic $(\mathrm{DPH})$ són atribució de l'organisme de conca (excepte les relatives a les obres i actuacions d'interès general de l'Estat, que corresponen al Ministeri de Foment ${ }^{41}$ ). En el cas de la conca hidrogràfica de l'Ebre i la del Xúquer, l'organisme de conca és la Confederació Hidrogràfica de l'Ebre $(\mathrm{CHE})^{42}$ i la Confederació Hidrogràfica del Xúquer (CHX) respectivament, i en el cas de les conques internes de Catalunya, l'organisme de conca és l'ACA ${ }^{43}$.

A part, en temes de custòdia del territori també s'han de tenir en compte les importants competències que l'Administració autonòmica i local disposen en matèries que afecten directament els espais aquàtics. Aquest és el cas dels espais adjacents a la llera, que ja no són de domini públic ${ }^{44}$, i que estan subjectes a matèries com urbanisme i ordenació del territori, temes agraris i forestals, o d'altres d'ambientals.

D'aquesta situació es desprèn que la diversitat de competències administratives i d'ens participants en els espais aquàtics pot suposar un obstacle o alentiment per aconseguir acords de custòdia ${ }^{45}$.

\section{3. Àmbit d'actuació de la custòdia fluvial}

Al llarg d'aquest apartat concretarem quins són els tipus d'espais aquàtics amb les diferents classificacions i a quin tipus d'acord de custòdia es pot arribar, i si realment té sentit plantejar els instruments de custòdia. Per exemple, queda clara la utilització de la custòdia per protegir el sòl privat sense protecció; però, en el cas dels espais naturals protegits en sòl públic, tindria sentit?

sentencia 30/2011, de 16 de marzo, una sentencia decepcionante", en Revista Andaluza de Administración Pública, núm. 79, 2011, pp. 419-423; RAZQUIN LIZARRAGA, J.A., "Las competencias autonómicas en materia de aguas (A propósito de las SSTC 30/2011 y 32/2011)”, en Revista Aranzadi Doctrinal, núm. 3, 2011, pp. 87-99.

${ }^{41}$ Art. 24 apartat a) del TRLA.

${ }^{42}$ Art. 22.1 del TRLA.

${ }^{43}$ Tot i que el text parla " $d$ 'Administració hidràulica", les competències són equivalents a les de l'òrgan de conca (art. 8 del Decret legislatiu 3/2003, de 4 de novembre, pel qual s'aprova el Text refós de la legislació en matèria d'aigües de Catalunya, TRLAC. DOGC núm. 4015, de 21/11/2003).

${ }^{44}$ Vegeu apartat 3 del capítol III d'aquest article.

${ }^{45}$ BARREIRA, A. (coord.) [et al.]; op. cit.; pp. 53-55. 
Més enllà del debat de la intervenció de la custòdia en les finques, pretenem avançar en el desenvolupament de les eines de la CF reflexionant si es pot intervenir també en els recursos naturals, com l'aigua, que són l'objecte de protecció dels acords de custòdia, i si l'actuació es pot fer independentment de la finca on es troben.

\subsection{Tipus d'espais naturals aquàtics (aigua dolça)}

Els espais aquàtics que hem tingut en compte són els superficials, ja que són els que solen ser objecte de la custòdia ${ }^{46}$ :

a) En el cas dels espais fluvials ${ }^{47}$, l'anàlisi parteix de la zonificació del riu i riberes que marca el Text refós de la llei d'aigües (TRLA) i el Reglament del domini públic hidràulic ${ }^{48}(\mathrm{RDPH})$.

- La llera del riu: està constituïda pel llit i la riba, i jurídicament es delimita pel terreny cobert en les màximes crescudes ${ }^{49}$. Aquest espai forma part del DPH.

- Zona de servitud: la formen els terrenys de cada marge, d'ús públic, de 5 metres d'amplada des del límit de la 1 lera ${ }^{50}$. En aquest espai es permeten determinats usos i funcions: protegir l'ecosistema fluvial i el DPH, permetre el pas de vianants i dels serveis de vigilància, conservació i salvament (a excepció que es consideri convenient limitar el pas per raons ambientals), permetre l'amarratge d'embarcacions de manera ocasional i en cas de necessitat. També es permet sembrar i plantar espècies no arbòries, sempre que no deteriorin l'ecosistema fluvial ni privin el pas ${ }^{51}$. En cas de plantació o tala d'arbres s'ha de requerir autorització administrativa.

\footnotetext{
${ }^{46}$ La custòdia en les aigües subterrànies està menys desenvolupada. Es podria centrar en la conservació dels espais naturals que recullen les aigües dels aqüífers per protegir-los de possibles impactes com la contaminació per purins o l'excessiva impermeabilització del sòl.

${ }^{47}$ Vegeu figura 1.

${ }^{48}$ Reial decret 849/1986, d'11 de abril, pel qual s'aprova el Reglament de domini públic hidràulic, que desplega els títols preliminars, I, IV, V, VI i VII de la Llei 29/1985, de 2 de agost, d'aigües. BOE núm. 157, de 02/07/1986. L'última modificació del RDPH, amb incidència en la zonificació de l'espai fluvial, és la que estableix el Reial decret 9/2008, d'11 d'abril. BOE núm. 14, de 16/01/2008.

${ }^{49}$ Art. 4 del TRLA.

${ }^{50}$ Art. 6 del TRLA, i art. 6 del RDPH.

${ }^{51}$ Art. 7.2 del RDPH.
} 
- Zona de policia: la formen els terrenys de cada marge de $100 \mathrm{~m}$ d'amplada des del límit de la llera ${ }^{52}$, tot $\mathrm{i}$ que es pot ampliar, seguint els requeriments necessaris ${ }^{53}$, per crear un espai de plana al·luvial (zona de flux preferent) on les crescudes no afectin els béns personals. Els usos que s'hi permeten estan condicionats a l'autorització de l'organisme de conca ${ }^{54}$ quan suposin una alteració substancial del relleu natural del terreny, les extraccions d'àrids, les construccions de tot tipus, siguin provisionals o definitives, i qualsevol ús o activitat que signifiqui un obstacle per al corrent en règim d'avingudes o que pugui ser causa de degradació o deteriorament de l'estat de la massa d'aigua, de l'ecosistema aquàtic i, en general, del DPH.

- Zona inundable: correspon als terrenys delimitats pels nivells teòrics que assolirien les aigües durant les avingudes amb un període de retorn de 500 anys. Aquests terrenys no són DPH, i conserven la qualificació jurídica i la titularitat dominical $^{55}$. Es considera que són espais on s'ha de garantir la seguretat de persones i béns, i el govern es reserva la possibilitat de limitar-ne els usos mitjançant un reial decret.

FIGURA 1. Zonificació de l'espai fluvial segons la legislació estatal d'aigües (Font: GODÉ 2008)

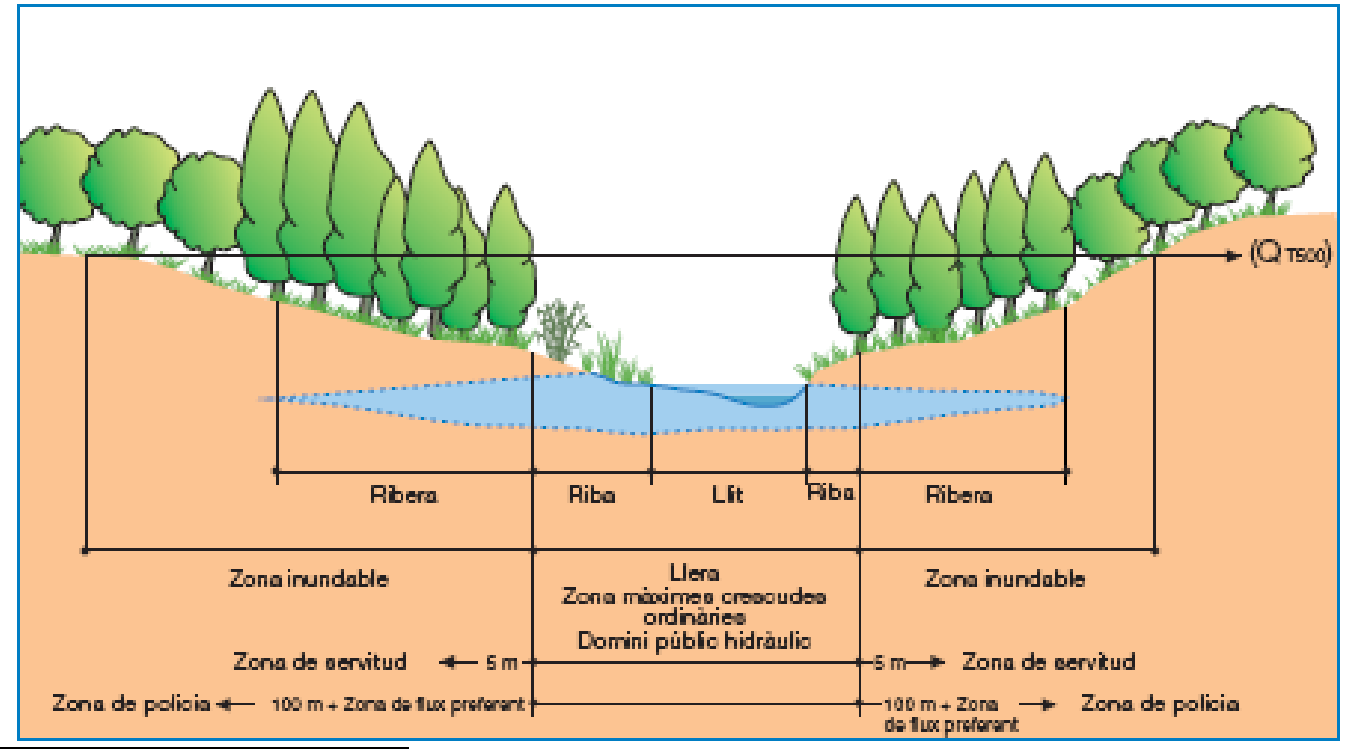

\footnotetext{
${ }^{52}$ Art. 6 del TRLA i art. 6 del RDPH.

${ }^{53}$ Art. 9.2 del RDPH.

${ }^{54}$ Art. 9.1 del RDPH.

${ }^{55}$ Art. 11 del TRLA i 14 del RDPH.
} 
b) En el cas de llacs, és DPH les lleres dels llacs, de les llacunes i dels embassaments superficials. Tota actuació en aquests espais requereix una intervenció de l'Administració pública. En canvi, una actuació en la riba o en els terrenys adjacents estarà condicionada a la titularitat privada o pública de les finques.

c) En el cas de les zones humides ${ }^{56}$, no es declaren en el llistat de DPH, ja que es consideren espais aquàtics diferents a la classificació als llacs ${ }^{57}$. Per tant, queda obert el debat de si la llera de les zones humides està considerada DPH. En tot cas, aquests medis aquàtics pertanyen al propietari de la finca on es troben (titularitat pública o privada).

\subsection{Espais naturals aquàtics on es pot aplicar la custòdia fluvial}

Per sintetitzar, dividirem els medis aquàtics de superfície que s'han presentat, entre els que estan sotmesos algun tipus de protecció i els que no, i els medis amb valors situats en finques de titularitat pública o privada.

En general, en els espais que ja gaudeixen d'algun tipus de protecció (siguin de titularitat pública o privada) gràcies a la normativa sectorial, es considera que els acords de custòdia no són tan prioritaris per preservar els valors naturals, culturals i paisatgístics de les finques.

Tanmateix, en els espais protegits, les entitats també poden intervenir per reforçar l'objectiu de conservació dels valors ambientals, encara que no utilitzin els instruments més clàssics de la custòdia. Per exemple, l'Associació Hàbitats és una entitat de custòdia que des de fa gairebé quinze anys realitza el "Projecte Rius" ambiental. Aquest projecte promou dues inspeccions l'any, en les quals els voluntaris

\footnotetext{
${ }^{56}$ Es considera que les zones humides són “extensions d'aiguamolls, pantans i torberes, o superfícies cobertes d'aigües, siguin aquestes de règim natural o artificial, permanents o temporals, estancades o corrents, dolces, salobres o salades, incloses les extensions d'aigua marina la profunditat en marea baixa no excedeixi de sis metres" (art. 1 del Conveni de Ramsar).

${ }^{57}$ En el camp de la limnologia, es distingeixen les zones humides dels llacs, llacunes i embassaments superficials perquè tenen menys profunditat, perquè tenen un caràcter temporal més marcat $i$ perquè tenen unes característiques de la qualitat química de l'aigua més diferenciades.

${ }^{58}$ Per a més informació, consulteu el web $<\mathrm{http}$ :// www.projecterius.org $>$.
} 
mesuren paràmetres sobre la qualitat ecològica dels rius ${ }^{59}$. Les inspeccions dels voluntaris són una eina molt útil per complementar la funció de vigilància de les administracions en l'espai fluvial.

En els espais sense cap tipus de protecció normativa, les entitats poden arribar a acords amb propietaris si la titularitat és privada. Si la titularitat dels espais és pública en part o exclusivament, es pot dubtar en la utilització dels instruments de custòdia, ja que estan més orientats als acords amb privats.

En aquest article defensem la validesa dels acords de custòdia en espais de titularitat pública, com ho demostra el reconeixement del rol que l'Administració pot dur a terme en la custòdia com a propietària de la finca ${ }^{60}$, i els acords ja existents que ho confirmen $^{61}$.

La normativa també dóna suport als acords de custòdia en finques públiques. Aquesta fórmula la recull la Llei 42/2007 en l'article 72.2, que descriu els acords per la cessió de la gestió amb la fórmula dels convenis administratius plurianuals: "La Administración General del Estado, cuando sea titular de terrenos situados en espacios naturales, podrá llevar a cabo el desarrollo de acuerdos de cesión de su gestión, total o parcial de los mismos, a entidades de custodia del territorio. Estos acuerdos para la cesión de la gestión, se establecerán por escrito en forma de convenio administrativo plurianual que preverá el sistema de financiación para su desarrollo, bien mediante aportaciones económicas, edificaciones, equipamientos, maquinaria, vehículos o cualquier otro bien o servicio, así como las directrices mínimas de gestión, fijadas en un precedente plan de gestión" $"$.

\footnotetext{
${ }^{59}$ Les entitats que volen fer un pas més i implicar-se en la recuperació de l'espai fluvial (incloent també l'espai que queda fora del DPH), poden adoptar un tram de riu a través d'acords de custòdia amb els propietaris privats i presentant un projecte de millora de l'espai fluvial que l'organisme de conca ha d'autoritzar. En el cas que el projecte de millora sigui dins el DPH, no cal establir un acord de custòdia amb l'organisme de conca, però aquest ha d'autoritzar el projecte. Vid. ASSOCIACIÓ HÀBITATS. Manual d'adopció de rius. Eines per a la implicació social en la gestió dels espais fluvials, 2a ed., Associació Hàbitats, Barcelona, 2009.

${ }^{60}$ Vegeu nota de peu núm. 4 d'aquest article.

61 Aquest és el cas dels acords de custòdia que el Grup de Natura Freixe ha establert amb l'antic Departament de Medi Ambient i Habitatge (actualment, Departament de Territori i Sostenibilitat) a través del conveni que recull el Programa Triennal de Custòdia a la reserva natural de Sebes i Meandre de Flix (Ribera d'Ebre). La Generalitat cedeix la gestió a l'esmentada entitat de custòdia sobre un espai que està protegit com a reserva natural de fauna salvatge, espai PEIN i espai dins la xarxa Natura 2000.

${ }^{62}$ Alguns autors qüestionen que els convenis administratius puguin ser considerats acords de custòdia, ja que defensen que aquests haurien de ser sotmesos al dret privat i no al dret públic. També posen en dubte la independència de les entitats de custòdia, que actuarien més com una entitat col·laboradora en
} 
L'esmentada normativa estatal estableix que els acords s'han d'establir amb l'Estat, però caldria ampliar aquesta fórmula a l'Administració autonòmica i a la local. També caldrà veure si el període de dos anys és suficient o no per dur a terme polítiques de gestió i conservació realistes i eficaces.

D'altra banda, també s'estan activant altres mecanismes de col·laboració entre entitats de custòdia i l'Administració pública, com és el cas del conveni de col·laboració entre l'ACA i l'XCT, per impulsar la custòdia en el marc dels programes de recuperació, gestió i conservació de l'entorn fluvial.

\section{Anàlisi dels acords de custòdia fluvial realitzats a Catalunya}

Per estudiar el potencial de la CF com a eina per al desenvolupament sostenible, s'han analitzat els acords de custòdia en finques amb valors i recursos naturals associats a medis aquàtics.

A partir de l'anàlisi, s'han establert quins són el tipus d'acord més utilitzats i la seva durada, quina és la titularitat de les finques on es realitzen els acords, quina és l'extensió total de zones protegides gràcies a acords de $\mathrm{CF}$, quin tipus d'entitats han establert algun tipus d'acord i l'evolució de la custòdia del territori com un mecanisme per assolir els objectius del desenvolupament sostenible.

a) Metodologia de càlcul

La informació utilitzada per fer els càlculs ha estat els inventaris d'acords i entitats de custòdia del territori a Catalunya, a les illes Balears i a Andorra que l'XCT ha realitzat

compliment d'un servei de l'Administració. Vegeu PALLARĖS SERRANO, A.; op. cit.; pp. 219-246. Es considera que la definició d'acord de custòdia no ha de restringir-se necessàriament a acords de dret privat. De fet, en la definició que s'ha escollit per al present article, que és la de l'XCT, no es fa aquesta limitació i es presenta la custòdia com un instrument ampli per "establir acords i vies de col·laboració entre agents públics i privats". Davant el repte de la protecció de la biodiversitat, s'han d'obrir al màxim el ventall de possibilitats d'acords, i no autolimitar-se. D'altra banda, és cert que el rol de l'entitat de custòdia es pot veure desfigurat si actua com "una entitat col·laboradora" de l'Administració, però la seva actuació està sotmesa al control dels seus membres i direcció, i de la mateixa Xarxa de Custòdia del Territori per avaluar si l'objectiu és la custòdia dels valors de la finca, i els instruments utilitzats els de custòdia, o bé d'altres . De totes maneres, recollim aquesta crítica per proposar en un futur, un "codi ètic" de les entitats de custòdia. 
en els anys $2003^{63}, 2005^{64}, 2007^{65}$ i $2009^{66}$, que elabora 1'XCT a partir d'una enquesta que omplen les entitats de custòdia.

Pel que fa al 2009, a part dels informes, també està disponible la base de dades que ha permès gestionar-la per obtenir més informació. Així, doncs, s'ha centrat l'anàlisi en l'any 2009, i quan les dades dels informes dels anys anteriors ho han permès, s'han realitzat les comparatives (per exemple, per establir l'evolució del nombre total d'acords de CF).

Entres les dades que es demanen en l'enquesta, les entitats de custòdia han d'assenyalar un màxim de tres valors de conservació (que han d'escollir entre 14 tipus) que consideren que tenen les finques on han establert acords de custòdia (sense necessitat de prioritzar-los).

Per seleccionar els acords de custòdia en finques que contenen medis aquàtics, s'han seleccionat les finques que tenien com a valors de conservació els relacionats amb el medi aquàtic, que segons la classificació proposada en l'enquesta podien ser "sistemes fluvials" (codi 10) o "zones humides" (codi 14). Com que eren les entitats les que atorgaven els valors de conservació a les seves finques, es podia donar el cas que, tot i ser finques amb medis aquàtics, haguessin oblidat d'anotar com a valors de conservació el de "sistemes fluvials" o de "zones humides". Per evitar aquest "error", s'han revisat totes les finques amb acords i s'han adjuntat les finques que pel nom s'interpretaven que eren espais aquàtics ${ }^{67}$ : basses, riera, estany, aiguamolls, desembocadura...

\footnotetext{
${ }^{63}$ MORENO, R; PIETX, J. (2003). I Inventari d'Acords i Entitats de custòdia del territori a Catalunya, les illes Balears i Andorra. Informes de la Xarxa de Custòdia del Territori, 17. [Recuperat el 22/11/2009, de : $<$ http://www.xct.cat/ca/cdr/informes.html $>$ ].

${ }^{64}$ SURINYAC, L.; MORENO, R. (2005). II Inventari d'Acords i Entitats de Custòdia del Territori a Catalunya, les illes Balears i Andorra. Informes de la Xarxa de Custòdia del Territori, 17. [Recuperat el 22/11/2009, de: <http://www.xct.cat/ca/cdr/informes.html $>$ ].

${ }^{65}$ BRONCANO, M.J.; COMAS, E.; PIETX, J. (2007). III Inventari d'Acords i Entitats de Custòdia del Territori a Catalunya, les illes Balears i Andorra. Informes de la Xarxa de Custòdia del Territori, 17. [Recuperat el 22/11/2009, de : <http://www.xct.cat/ca/cdr/informes.html $>$ ].

${ }^{66}$ PUIG, M.; MASÓ, M. (2009a). IV inventari d'Acords i Entitats de Custòdia del Territori a Catalunya, les illes Balears i Andorra. Informes de la Xarxa de Custòdia del Territori, 17. [Recuperat el 22/11/2009, de $<$ http://www.xct.cat/ca/cdt/inventari.html $>$ ].

${ }^{67}$ Per exemple: una entitat que té un acord de custòdia en una finca que rep el nom de "Riera de Cogolls", i que en omplir l'enquesta havia oblidat d'indicar els valors de conservació. Gràcies a la segona criba també s'ha addicionat aquest acord al total de finques amb medis aquàtics que estan custodiades.
} 
b) Resultats i discussió

En total, s'han establert 176 acords de custòdia que es desglossen en la següent tipologia:

1. L'acord verbal.

2. El contracte de custòdia del territori.

3. L'arrendament de serveis i mandat.

4. La cessió d'ús i arrendaments.

5. La donació i la compravenda.

La durada mínima dels acords és d'un any; i la màxima, un acord indefinit.

La figura 2 mostra que el tipus d'acord més utilitzat és el contracte de custòdia del territori (el 48\% del total d'acords), amb la durada més habitual d'entre 1 i 5 anys. Seguidament, l'acord més utilitzat és el conveni territorial, que fa referència als acords de custòdia assolits per l'Obra Social de CatalunyaCaixa ${ }^{68}$. Aquest tipus d'acord en finques amb medis aquàtics, que representa el 16\% del total, és molt específic pel tipus d'entitat de custòdia, ja que es tracta majoritàriament d'acords en finques de titularitat pública i d'una durada d'un any, amb la possibilitat de renovar-se anualment.

El següent acord més emprat és l'acord verbal (15\% del total), que sorprèn perquè pràcticament en tots els casos s'estableix amb una durada indefinida. Es podria creure que aquesta durada seria específica per als acords en què es busca més seguretat jurídica, com la "cessió i l'arrendament", la "compravenda" i la "donació". Tanmateix, cal destacar que la voluntarietat i la confiança mútua entre les entitats, l'Administració i els propietaris, també tenen prou pes per establir acords indefinits, encara que "només" tingui el valor de la paraula.

Els acords menys utilitzats (amb percentatges inferiors al 10\%) són el d'“arrendaments de serveis i mandat", els de "donació" i els de "compravenda".

Es considera que són un símptoma que la custòdia encara és molt jove a Catalunya, ja que hi ha certa desconfiança del propietari a deixar la visió productiva de la terra per una visió conservacionista. Segurament, el motor del canvi serà el reconeixement de l'eina de la custòdia com una estratègia eficaç per a la millora del paisatge, qualitat de

\footnotetext{
${ }^{68}$ Anteriorment, Fundació Territori i Paisatge de Caixa Catalunya.
} 
vida i sostenibilitat del territori, i, d'altra banda, una legislació que permeti incentius als propietaris que optin pels acords de custòdia.

FIGURA 2. Tipus d'acords de custòdia fluvial vigents i durada (2009). Font: elaboració pròpia a partir de IV l'inventari d'acords de l'XCT ${ }^{69}$ (2009)

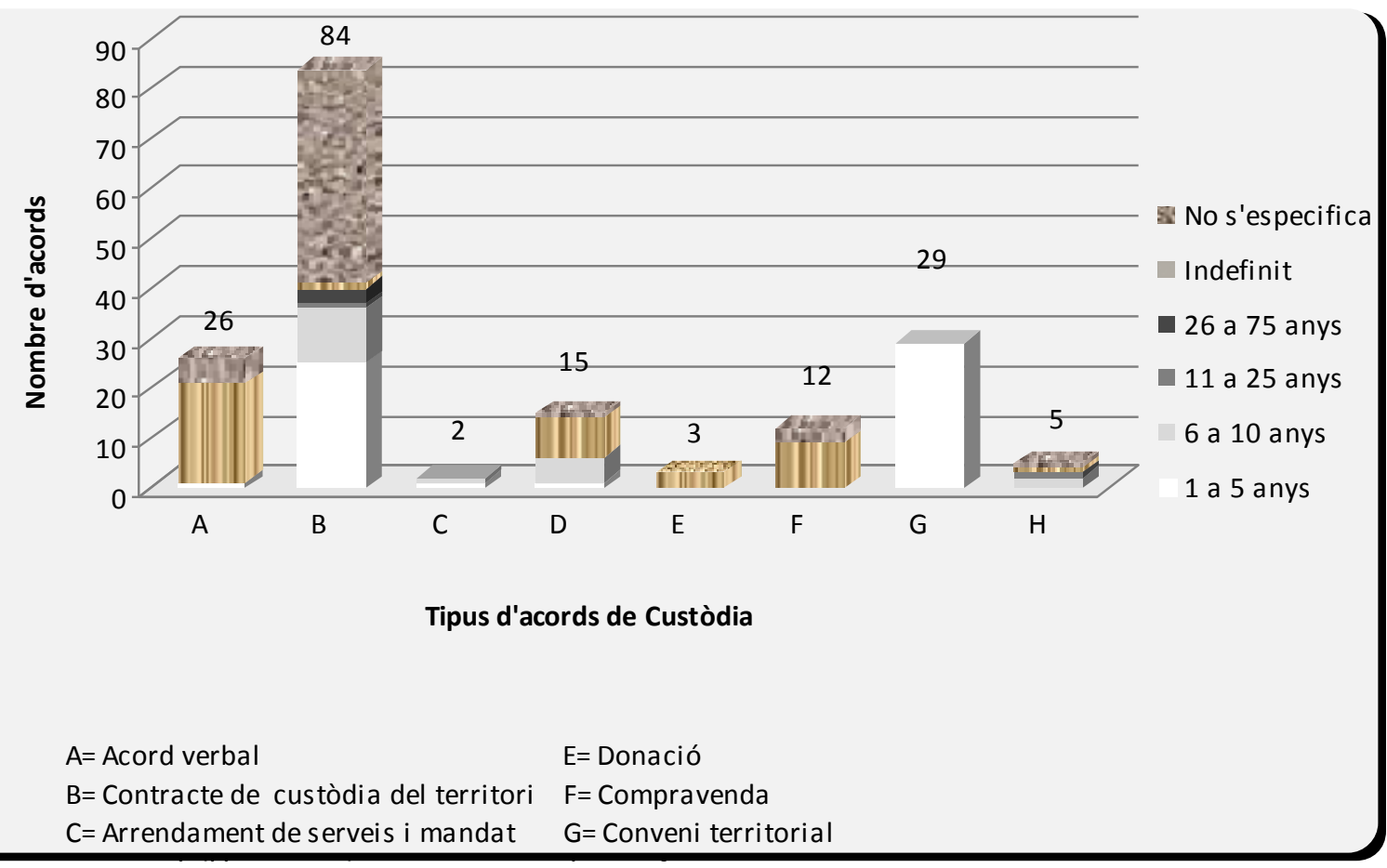

Una altra dada interessant és conèixer quina és la titularitat de les finques custodiades. La figura 3 mostra, com era d'esperar, que la major part dels acords es produeixen en les finques privades (69\%), en què la fórmula de la CF s'aplica més plenament. Però el nombre d'acords en finques públiques és força important $(28 \%)$, i deixa entreveure el potencial de la custòdia en finques independentment de la seva titularitat.

Quan la finca té més d'un propietari, es pot donar el cas que es realitzin els acords amb propietaris públics i privats. Aquest és el cas del $2 \%$ dels acords.

\footnotetext{
${ }^{69}$ PUIG, M.; MASÓ, M. (2009b). Base de Dades del IV inventari d'Acords i Entitats de Custòdia del Territori a Catalunya, les illes Balears i Andorra. Informes de la Xarxa de Custòdia del Territori, 17. [Recuperat el 22/11/2009, de : <http://www.xct.cat/ca/cdt/inventari.html $>$ ].
} 
FIGURA 3. Titularitat de les finques on s'han establert acords de custòdia fluvial (2009). Font: elaboració pròpia a partir de IV l'inventari d'acords de l'XCT (2009)

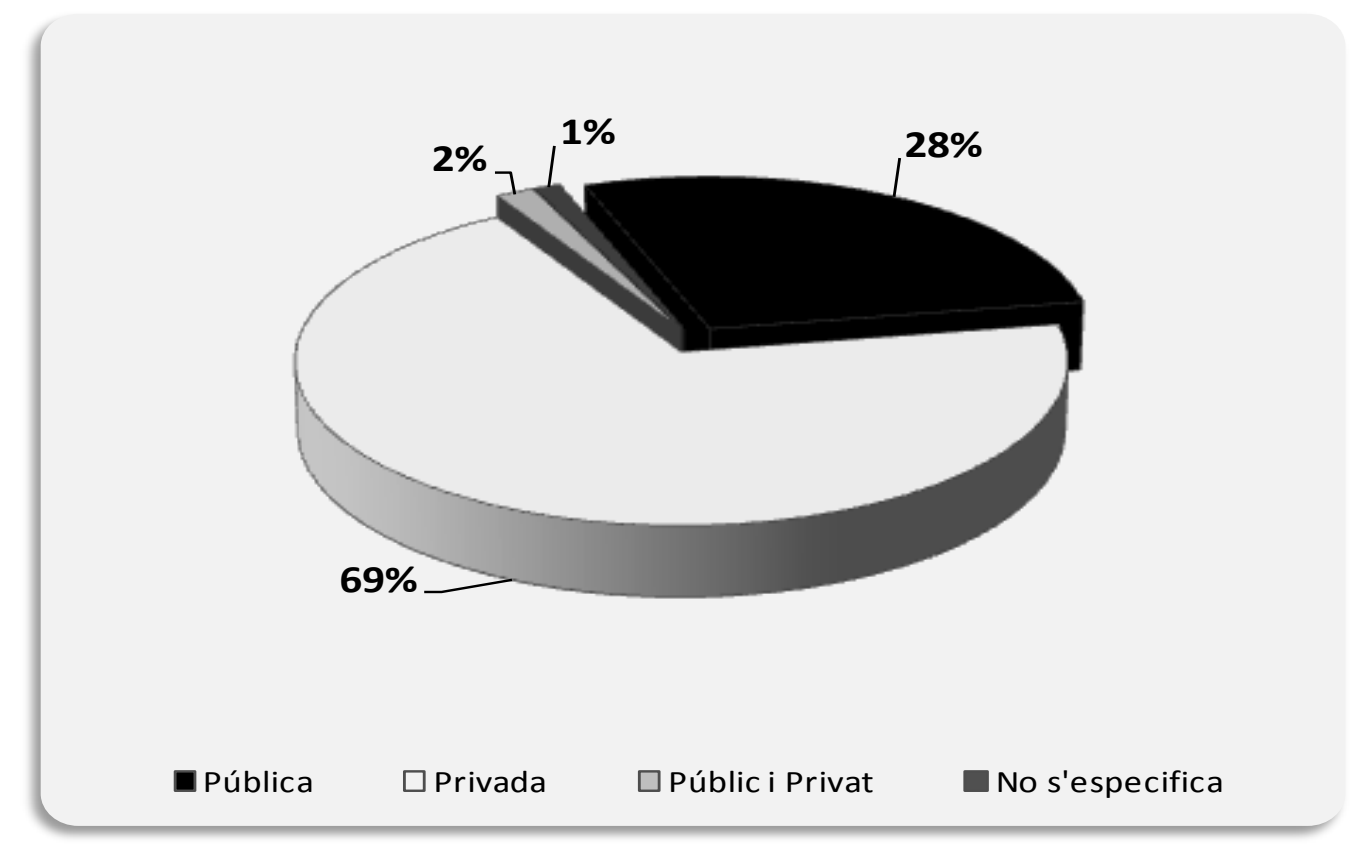

Els 176 acords de CF augmentaran la conservació d'un total de finques que comprenen una extensió de 31.892,26 ha. En la figura 4 observem que el 97\% d'aquests terrenys custodiats $(30.952,11$ ha) es troben en finques de titularitat pública, i posa de manifest que, tot i el menor nombre d'acords, aquests són de més extensió que en les finques privades.

La menor extensió total de finques amb acords amb privats es pot explicar per la complexitat de la negociació amb els propietaris privats i la diversitat d'aquests actors, que limiten els acords a espais molt determinats i no els estenen fàcilment a la totalitat de la finca, com sol ser el cas de les finques de titularitat pública. 
FIGURA 4. Relació de l'extensió amb la titularitat de les finques amb acords de custòdia fluvial (2009). Font: elaboració pròpia a partir de IV l'inventari d'acords de l'XCT (2009)

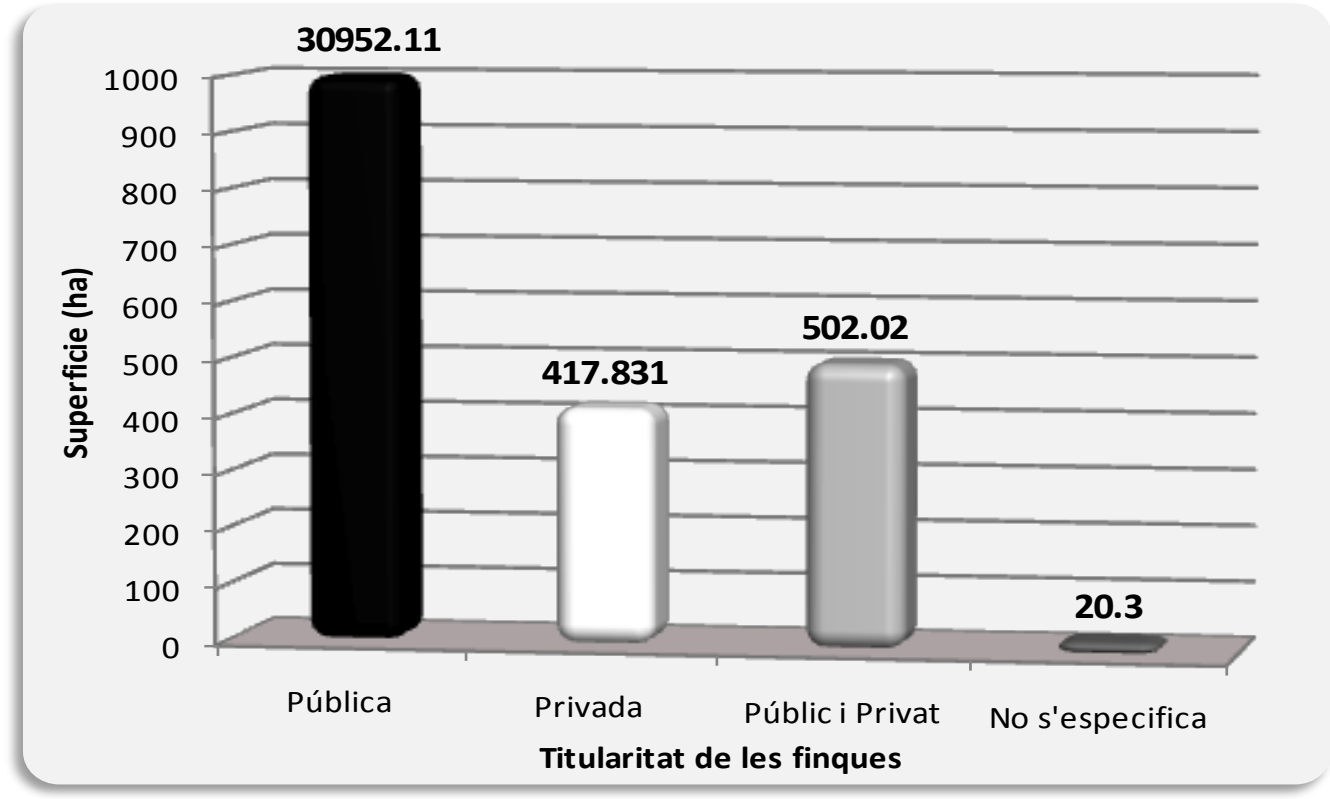

També cal tenir present que la major part de l'extensió de les finques públiques (el 90\% de les 30.952,11 ha) es concentra en tres finques, que són custodiades per l'entitat Obra Social de CatalunyaCaixa:

- Conca de la riera d'Àlguema (12130 ha).

- Capçalera del riu Rialb (14503 ha).

- Estany de Banyoles i el seu entorn (1030,58 ha).

Tanmateix, sense aquests tres acords, les finques públiques continuen sent les d'extensió més gran i representen el 78\% del total (3.288,53ha).

Pel que fa al nombre d'entitats que tenen algun tipus d'acord de CF en actiu durant el 2009, n'hi ha un total de 29. No hem tingut accés al nombre d'entitats que han establert acords de CF en els anys precedents, i, per tant, no podem establir quina evolució s'ha produït. En tot cas, considerem que 29 entitats és un nombre destacat que indica que hi ha una "activitat social" important per a la conservació dels valors naturals del territori, que mostra el compromís de les entitats com un actor que cal tenir en compte en la gestió i protecció dels espais naturals. Entre les 29 entitats, destaca "Minyons Escoltes i 
Guies de Catalunya" "70, que és l'entitat que ha establert un nombre més gran d'acords amb un total de 54.

La major part d'aquestes entitats són "privades sense ànim de lucre", com mostra la figura 5, i tenen com a finalitat la conservació del medi natural. Tal com hem explicat, aquest tipus d'entitats són les que s'adapten millor als mecanismes de custòdia del territori. Tot i així, les administracions públiques també poden participar en la custòdia del territori, actuar com a promotores dels acords entre un propietari privat i una entitat de custòdia, o bé com a titulars dels espais amb valors naturals, i establir, directament, acords amb les entitats. En el cas de la CF, la participació de les administracions públiques és reduïda (12\%), però implica ajuntaments, una diputació (Diputació de Girona), i un consorci públic (Consorci de l'Estany).

FIGURA 5. Entitats de custòdia fluvial privades i públiques. Font: elaboració pròpia a partir de IV l'inventari d'acords de l'XCT (2009)

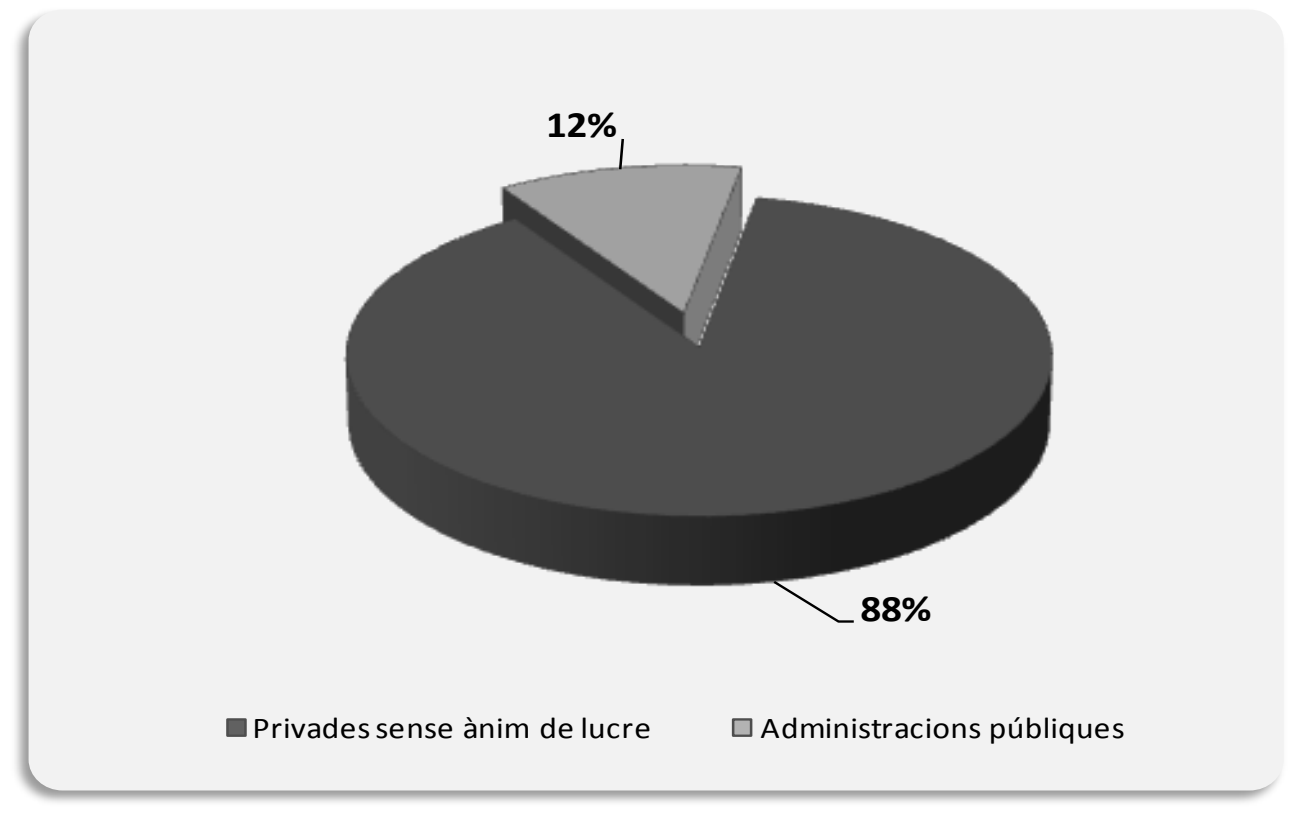

Finalment, l'anàlisi de l'evolució del nombre d'acords ens pot aportar informació sobre si els mecanismes de custòdia són una estratègia vàlida per al desenvolupament sostenible, ja que mostren si aquests instruments s'apliquen i es consoliden, o si al contrari, els límits i les dificultats de la custòdia són un obstacle infranquejable.

\footnotetext{
${ }^{70}$ Per a més informació sobre l'entitat, consulteu: $<$ http://www.escoltesiguies.cat $>$.
} 
La figura 6 mostra un augment constant del nombre d'acords de custòdia des del 2003, i un augment molt destacat el 2009, ja que passen de 12 acords (2003) a 176 (2009). Aquest boom dels acords de custòdia mostra que es tracta d'una estratègia cada vegada més utilitzada, i que els actors del territori veuen el seu potencial, en contra de les decisions més "unilaterals" que la mateixa administració pot prendre a l'hora d'aplicar polítiques de gestió dels espais naturals i que poques vegades integren els interessos $\mathrm{i}$ les inquietuds d'altres actors implicats.

FIGURA 6. Evolució dels acords de custòdia fluvial (2003-2009). Font: elaboració pròpia a partir dels inventaris d'acords de l'XCT (2003, 2005, 2007 i 2009)

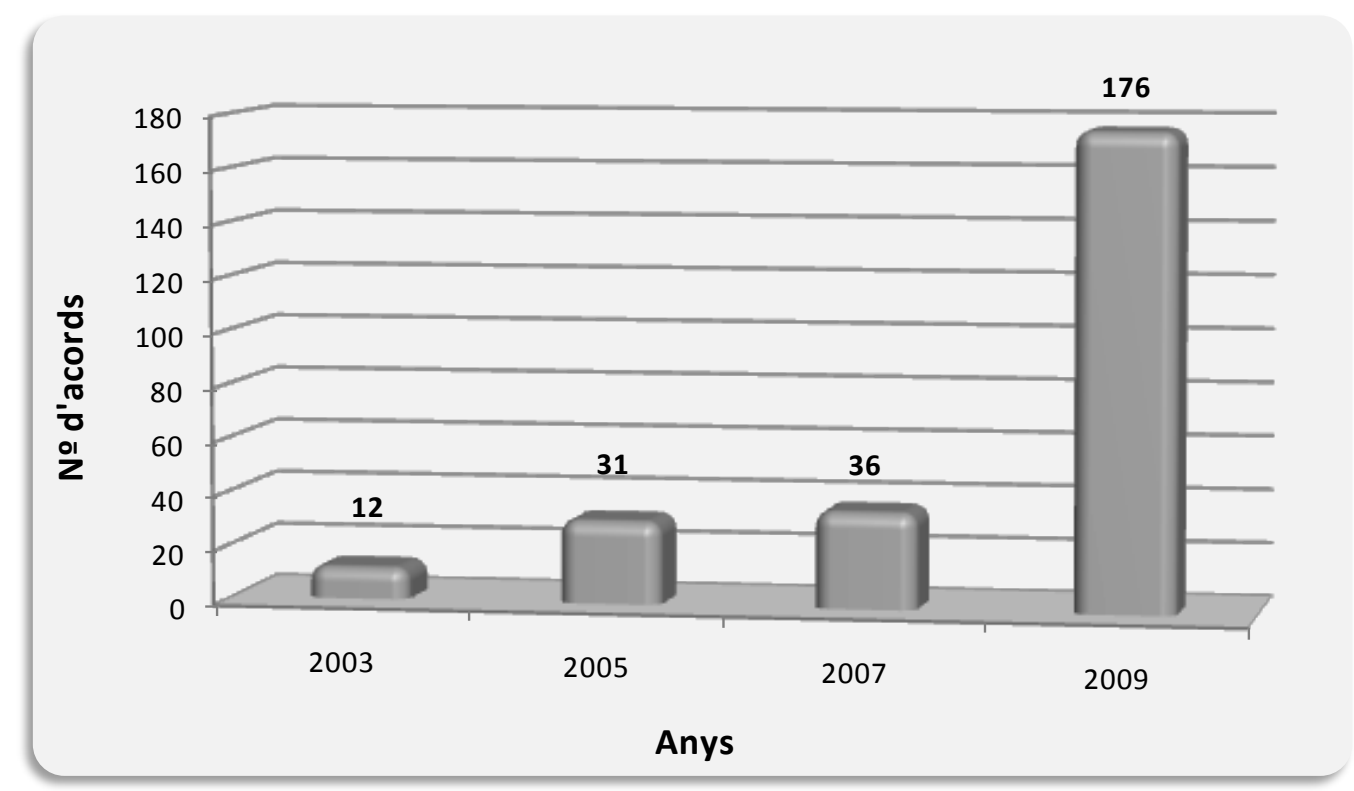

Aquesta tendència de fort creixement en els acords de custòdia fluvial també es percep en el conjunt d'acords de la custòdia del territori, tal com es pot observar en la figura 7: 
FIGURA 7. Evolució del nombre d'acords de custòdia del territori durant el periode 1980-2009. Font: elaboració pròpia a partir de IV l'inventari d'acords de l'XCT ${ }^{71}$ (2009)

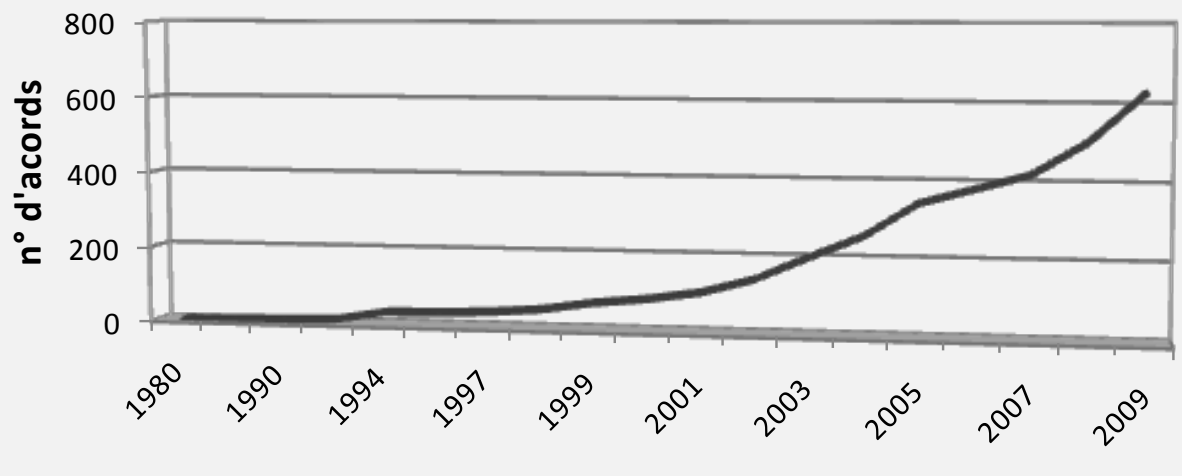

Anys

Interpretem, doncs, que la CF s'està consolidant com una estratègia vàlida per al desenvolupament sostenible, ja que els 176 acords en actiu durant el 2009 han permès protegir una extensió de 31.892, 26 ha, que sense la participació de la custòdia no hagi estat possible.

\section{Intervenció de la custòdia fluvial sobre el recurs de l'aigua}

En l'estratègia de conservació i gestió del territori, la custòdia és un instrument que fins ara s'ha desenvolupat més en la intervenció de l'espai físic, en les finques, que en els recursos naturals pròpiament, tot i que la Llei 42/2007 no ho limita específicament ${ }^{72}$.

\footnotetext{
${ }^{71}$ PUIG, M.; MASÓ, M. (2009b); op. cit.; p. 12.

${ }^{72}$ A partir de la definció de custòdia del territori de l'article 3 apartat 9 de la Llei 42/2007: “conjunto de estrategias o técnicas jurídicas a través de las cuales se implican a los propietarios y usuarios del territorio en la conservación y uso de los valores y los recursos naturales, culturales y paisajísticos", es pot interpretar que aquests instruments també són aplicables per a la conservació i l'ús dels recursos naturals, com l'aigua.
} 
Ens podem trobar en el cas que el propietari del recurs (pou, mina...) no sigui el mateix que el de la finca, i, per tant, els acords tradicionals de custòdia poden ser poc efectius per a la seva conservació. En aquest apartat, es plantegen nous instruments per la CF per intervenir directament sobre el recurs de l'aigua.

\subsection{L'aigua: un recurs que cal custodiar}

L'aigua és un recurs natural que forma part del $\mathrm{DPH}^{73}, \mathrm{i}$, com a tal, sota la tutela $\mathrm{i}$ l'Administració de l'Estat, o d'algun altre subjecte públic si així ho determina la llei.

Així com els altres béns de domini públic ${ }^{74}$, l'aigua també es caracteritza perquè és un bé inalienable (no es pot transmetre la propietat d'aquests béns), imprescriptible (la seva ocupació o utilització no suposa consolidar drets de propietat) i inembargable (no pot servir de garantia per al compliment d'obligacions d'embargament).

Aquestes característiques limiten l'acció de la custòdia, més orientada a acords amb propietaris. En el cas de l'aigua, doncs, no es pot parlar pròpiament d'un propietari d'aquests béns, ja que es considera que són de la comunitat en general, sinó d'un aprofitament que pot ser públic o privat, i que ha de respectar l'interès general $\mathrm{i}$ ha d'estar sotmès al control de l'Administració ${ }^{75}$.

Així, la utilització d'aquests béns pot realitzar-se a través d'usos comuns (que són els que corresponen de manera igual a tots els ciutadans indistintament, sense generar competència d'ús), i d'usos privatius (que suposen un aprofitament en benefici propi, que limita o exclou la utilització del bé per part d'altres interessats).

En el cas dels usos comuns, es diferencien els "usos comuns especials" que requereixen una declaració responsable ${ }^{76}$, o una autorització ambiental si la intensitat dels usos pot

\footnotetext{
${ }^{73}$ Art. 2 del TRLA.

${ }^{74}$ Les característiques jurídiques dels béns demanials estan recollides en l'article 132 de la CE.

75 ALCAIN MARTÍNEZ, E., El aprovechamiento privado del agua y su protección jurídica, Bosch, Barcelona, 1994, pp. 36-37.

${ }^{76}$ Es reclama per a l'exercici de la navegació i flotació, l'establiment de barques i embarcadors, i per a qualsevol altre ús diferent al de banyada, beure, altres usos domèstics i per abeurar el ramat, que no exclogui la utilització del recurs per part de tercers. La declaració responsable (art. 3.9 i 7 de la Llei 17/2009, de 23 de novembre, sobre el lliure accés de les activitats de serveis i el seu exercici. BOE núm. 286, de 24/11/2009), s'ha de presentar en un període mínim d'antelació de 15 dies, per tal de comprovar la compatibilitat dels usos esmentats amb les finalitats del DPH. La presentació de la declaració responsable es regula en els articles 51 i 51 bis, art 55-70 del RDPH.
} 
dificultar la utilització de tercers ${ }^{77}$. En el cas dels usos privatius, el dret a l'ús s'adquireix per concessió $^{78}$ (atorgada per un màxim de 75 anys) o per disposició legal ${ }^{79}$. Arribats a aquest punt, es planteja una possibilitat d'acord de custòdia: 1'Administració, com a òrgan gestor d'aquests béns, podria cedir-ne la gestió a les entitats de custòdia, com a representants de la societat i amb la voluntat d'assegurar l'objectiu de l'interès general (conservació dels valors ambientals). En aquest cas, els instruments de custòdia més adequats podrien ser la cessió d'ús o l'arrendament.

Es recomana que per donar més estabilitat i seguretat jurídica a aquest tipus d'acords entre les entitats de custòdia i l'Administració, aquest es detalli en el marc d'un conveni administratiu. Aquesta opció es planteja d'acord amb als convenis administratius plurianuals expressament previstos en l'article 72.2 de la Llei 42/2007, del patrimoni natural i la biodiversitat.

D'altra banda, la intervenció sobre l'ús de l'aigua ha de tenir en compte que no implica en cap cas un dret real sobre el recurs sinó un dret sobre l'aprofitament d'aquest recurs, que està regulat per l'Administració a través de les autoritzacions, declaracions responsables i les concessions administratives.

Les entitats de custòdia podrien intervenir, en el moment que s'atorguen les concessions administratives (i també quan es modifiquin o revisin) ${ }^{80}$ per introduir criteris d'ús sostenible de l'aigua (cas que es podria aplicar pels cabals de manteniment, i que s'explica en l'apartat següent).

\footnotetext{
${ }^{77}$ Es consideren usos comuns especials que poden afectar la utilització de tercers l'aprofitament d'àrids, de vegetació arbòria o arbustiva, l'establiment de ponts o passarel·les o instal·lacions per banys públics, sembres, plantacions i tala d'arbres en terrenys de DPH (art. del 72 al 77 del RDPH). El procediment d'atorgament d'autoritzacions respecta els principis de publicitat, transparència i objectivitat, així com el de concurrència competitiva, en els termes previstos en la Llei 30/2007, de 30 d'octubre, de contracte del sector públic. BOE núm. 261, de 31/10/2007.

${ }^{78} \mathrm{La}$ concessió per a usos privatius de l'aigua és regula en l'article 59 del TRLA, i en els articles del 93 al 170 del RDPH.

${ }^{79}$ Art. 54 del TRLA i art. 84, 85, 87 i 88 del RDPH.

${ }^{80}$ El RDPH preveu un període d'exposició pública per a les concessions i les obres associades (art. 109 i ss). És en aquest tràmit que les entitats de custòdia poden presentar al-legacions per introduir criteris ambientals. Caldria estudiar específicament el cas de projecte hidràulics que afecten una concessió i que han de ser objecte d'avaluació d'impacte ambiental segons la normativa vigent. En aquest últim cas, s'hauria d'estudiar la jurisprudència, i consultar a les autoritats competents (ACA, Departament de Territori i Sostenibilitat...), que s'haurien de pronunciar sobre si el procediment per presentar les al·legacions ha de seguir la llei d'aigües segons l'article 109 i ss. del RDPH, o bé la legislació vigent sobre avaluació d'impacte ambiental.
} 
En el cas de les declaracions responsables, les entitats de custòdia poden vetllar per tal que s'avaluïn correctament els efectes sobre el medi ambient, la salubritat i els recursos pesquers, en el cas dels usos comuns especials del DPH realitzats en la llera ${ }^{81}$.

Si es requereix autorització ambiental, a causa de la intensitat dels usos comuns especials, també podria dur a terme la mateixa tasca que en les concessions aprofitant la flexibilitat de l'Administració per fixar-ne els requisits.

D'altra banda, tot i que les aigües són béns de domini públic, excepcionalment, hi ha aigües que mantenen la consideració de privades, independentment de la propietat de la finca on neixin, discorrin o s'estanquin. Aquest és el cas de les aigües de pluja ${ }^{82}$, i les aigües subterrànies quan existien drets adquirits anteriors a la llei d'aigües (LA $)^{83}$.

Es qüestiona si aquestes aigües són apropiables exclusivament a un propietari privat ${ }^{84}$. Es defensa que les característiques del bé, un recurs escàs, obliguen a sotmetre el recurs a algun tipus de control de l'Administració. Així ho determina la normativa: en el cas de les aigües de pluja, es limita l'aprofitament al que disposa el TRLA, al respecte del dret a tercers, i la prohibició de l'abús del dret ${ }^{85}$. En el cas de les aigües subterrànies, per l'aprofitament d'aigües públiques o privades, els són aplicats els condicionants que es derivin de la normativa referent a la sobreexplotació d'aqǘfers, els usos de l'aigua en cas de sequeres greus o d'urgent necessitat, i les relatives a les limitacions dels usos del $\mathrm{DPH}^{86}$. En qualsevol cas, la llei tampoc empara l'abús de la utilització de l'aigua, el malbaratament ni el mal ús del recurs ${ }^{87}$.

\footnotetext{
${ }^{81}$ Art. 52 del RDPH.

${ }^{82}$ Independentment de si les aigües de pluja cauen en finca pública o privada, aquestes són de titularitat privada segons la STC 227/1988 ( $\mathrm{Fj}$. núm. 23, apartat e)). Aquesta sentència ha estat molt criticada per la doctrina i poc aplicada. Vid. MOREU BALLONGA, JL., Aguas públicas y aguas privadas, Bosch, Barcelona, 1996, p. 325-327.

${ }^{83}$ Llei d'aigües 12/1985, de 2 d'agost, d'aigües. BOE núm. 103, de 30/04/1986. Pels drets adquirits anteriors a la LA, els propietaris podien escollir entre gaudir de la protecció administrativa en sol-licitar la inscripció al Registre d'Aprofitament d'Aigües (RA) com un aprofitament temporal a través d'una concessió per a cinquanta anys, o mantenir la propietat privada (disposició transitòria $2 \mathrm{a}$ a $4 \mathrm{a}$ de la LA i del TRLA).

84 “"En ningún momento, ni la Ley ni sus Reglamentos hacen referencia a la propiedad de estas aguas; sólo se hace referencia de forma muy genérica en (...) las disposiciones transitorias" (LA). MORELL OCAÑA, L., "Las titularidades sobre aguas privadas", en Revista de Administración Pública, Madrid, núm. 154, 2001, p. 8. Altres autors qüestionen si es confon el dret de propietat amb el dret d'aprofitament, o si coexisteixen els dos drets. Vid..ALCAIN MARTÍNEZ, E.; op. cit.; pp. 69-71.

${ }^{85}$ Art. 54.1 del TRLA.

${ }^{86}$ Art. disposició transitòria 2a a 4a de la LA i del TRLA.

${ }^{87}$ Art. 50.1 del TRLA.
} 
En el cas de les aigües subterrànies privades, la intervenció de les entitats de custòdia pot ajudar a aclarir algunes ombres de la TRLA, encara que no sigui la seva finalitat. Per exemple, per donar constància a l'administració dels casos en què els aprofitaments d'aigües privades atorgats per una legislació anterior a la LA, no consten en cap catàleg, o quan a més, aquestes puguin ser renovades amb una nova concessió. Amb aquesta actuació es pot ajudar a evitar la sobreexplotació d'aqüífers, conèixer millor els recursos hídrics de la conca, i fer una planificació més correcta per protegir els recurs hídrics.

En el cas de les aigües de pluja, la intervenció de la CF podria servir per millorar el coneixement sobre els aprofitaments existents d'aquest recurs i per verificar que no es perjudica la recàrrega de cap aqǘfer protegit, i es millora, doncs, la conservació dels recursos hídrics.

\subsection{Projectes d'innovació en custòdia fluvial}

A. Garantia dels cabals de manteniment

Un dels principals conflictes en els usos de l'aigua és degut a les nombroses captacions que es produeixen al llarg dels rius i que poden tenir un efecte pertorbador sobre els ecosistemes fluvials.

Per fer-hi front, el Govern de la Generalitat de Catalunya, en la sessió de 4 de juliol de 2006, va adoptar l'acord pel qual s'aprova el Pla Sectorial de Cabals de Manteniment de les Conques Internes de Catalunya ${ }^{88}$, que té l'objectiu d'establir els cabals per garantir el manteniment de la qualitat ambiental acceptable.

Els cabals de manteniment són una restricció que s'imposa amb caràcter general en els trams de rius on hi ha sistemes d'explotació com les captacions d'aigua, que són incompatibles amb els objectius de qualitat ambiental que fixa la DMA. Els cabals de manteniment s'estimen en el punt en què l'ús antròpic ja supera els límits acceptables de qualitat ambiental.

Les entitats de custòdia podrien ser una peça important per garantir l'equilibri d'interessos entre la voluntat d'explotació del recurs i la necessitat de preservar la

\footnotetext{
${ }^{88}$ Resolució MAH/2465/2006, de 13 de juliol.
} 
qualitat ecològica dels ecosistemes fluvials, tal com estableixen la DMA i la normativa estatal $^{89}$.

La seva intervenció podria ser a partir de les fórmules de conveni i col·laboració, com ara convenis i el contracte de riu que estableix el mateix Pla Sectorial de Cabals de Manteniment de les Conques Internes de Catalunya, en el cas de modificació de característiques, de revisió o de transmissió de títols concessionats. Els convenis resten supeditats al que prevegi el corresponent pla zonal de cabals de manteniment $i$, en tot cas, han d'estar expressament previstos en alguna norma.

L'actuació de les entitats de custòdia obre noves vies per introduir criteris de sostenibilitat en la gestió de les captacions d'aigua. Aquest treball es planteja a diferents escales, ja que les explotacions de l'aigua poden provenir des d'un petit particular fins a les grans empreses hidroelèctriques.

Un dels sectors en els quals es podria plantejar un primer "experiment" per avaluar l'actuació de les entitats de custòdia, podria ser en les comunitats de regants que utilitzen les quantitats d'aigua fixades en les concessions administratives. La proximitat de les entitats de custòdia amb el territori pot ser un factor clau en l'entesa i en el compromís per introduir criteris de gestió sostenibles entre els regants (nous sistemes de reg més eficaços, plantar varietats locals més adaptades, variar la quantitat d'aigua que s'ha de distribuir entre els regants tenint en compte períodes de restricció...). Cal tenir present que moltes comunitats de regants funcionen de forma il·legal perquè no tenen concessions administratives, i que són reticents a qualsevol tipus de control. En aquest context, l'actuació de les entitats permetria un procés dialogat i consensuat per a la seva legalització.

L'experiència guanyada en aquest projecte amb comunitats de regants seria de gran ajut per afrontar en un futur la gestió sostenible de les explotacions que fan les grans hidroelèctriques, molt més complex pels interessos en joc i per la quantitat d'aigua que s'ha de gestionar.

El principal problema que es poden trobar les entitats de custòdia en la intervenció en les aigües regenerades és que la inactivitat de les administracions a l'hora de garantir els

\footnotetext{
${ }^{89}$ En aplicació de l'article 18 del RD 907/2007, de 6 de juliol, pel qual s'aprova el Reglament de la planificació hidrològica. BOE núm. 162, de 7/07/2007.
} 
cabals de manteniment les obligui a actuar com a òrgan de control extern, cosa que no és la finalitat d'aquestes associacions.

B. Intervenció en la gestió de les aigües regenerades

Una nova font alternativa de recurs d'aigua són les aigües regenerades que provenen de les estacions de depuració de aigües residuals (EDAR), i que han estat sotmeses a un tractament addicional per dotar-les de la qualitat fisicoquímica i sanitària ${ }^{90}$ que les fan aptes per a diferents usos com: els usos urbans (reg de jardins privats, descàrrega aparells sanitaris, reg d'espais públics, neteja de carrers, sistemes contra incendis, rentat industrial de vehicles), els usos agrícoles, els usos industrials excepte la indústria alimentària, els usos recreatius (reg de camps de golf, estanys o basses ornamentals) i els usos ambientals (recàrrega d'aqüífers, manteniment de cabals o aportacions d'aigua a zones humides).

A través del Programa de Reutilització d'Aigua de Catalunya ${ }^{91}$ (actualment, juliol 2011, en tràmit), l'ACA enumera les actuacions de reutilització que s'han de dur a terme per aprofitar el màxim dels $700 \mathrm{hm}^{3}$ d'aigua depurada que estima l'ACA, i que han d'anar encaminades a assolir els percentatges següents: ús agrícola (30\%), ús industrial (26\%), ús ambiental (25\%), ús urbà (12\%), i ús recreatiu $(7 \%)$.

Per a aquest nou recurs, les entitats de custòdia poden aportar actuacions innovadores:

- En el cas que siguin depuradores gestionades per entitats públiques, l'ús de les aigües regenerades ha d'estar sotmès a la intervenció administrativa. Aleshores, les entitats de custòdia podrien sol·licitar concessions per a l'ús ambiental d'aquestes aigües (que es preveu que suposarà el 25\% el 2015). Aquesta aigua podria ser destinada, per exemple, a finques custodiades, en què el pla de gestió corresponent en preveiés l'ús per millorar la biodiversitat de la finca.

\footnotetext{
${ }^{90}$ Criteris establerts pel Reial decret 1620/2007, de 7 de desembre, pel qual s'estableix el règim jurídic de la reutilització de les aigües depurades. BOE núm. 294, de 08/12/2007.

${ }^{91}$ AGÈNCIA CATALANA DE L'AigUA. (2009). Programa de Reutilització d'Aigua a Catalunya. [Recuperat el 15/011/2009 de: < http://acaweb.gencat.cat/aca/documents/ca/planificacio/reutilitzacio/PRAC_V_3_1.pdf $>$ ].
} 
- En aquest cas, les entitats de custòdia també podrien introduir criteris ambientals en les concessions administratives per als altres usos (municipal, industrial, recreatiu i agrícola), com hem explicat anteriorment.

Quant als usos ambientals d'aquestes aigües, caldria presentar algunes limitacions que poden afectar l'actuació de les entitats de custòdia, per exemple, en el cas que volguessin utilitzar aquesta aigua per mantenir un cabal en rius amb acords o sense acords de custòdia. L'ACA considera que aquestes aigües no formen part de la conca i que, per tant, no poden anar destinades als cabals de manteniment. Una part molt important de municipis catalans s'abasteix d'aigua d'altres conques (aigua procedent d'Aigües Ter-Llobregat) i el nou recurs que es genera es creu que s'ha de destinar a alliberar els usos comuns de l'aigua (per exemple, per alliberar usos agrícoles de l'aigua de pous).

D'altra banda, la intervenció en les concessions administratives, també pot afavorir que les entitats de custòdia destinin una part massa important de la seva actuació a controlar l'Administració i no a gestionar espais o recursos naturals, més en acord amb la seva finalitat.

\section{LÍMITS DE LA CUSTÒDIA}

Tot i la proliferació d'acords de custòdia i d'entitats de custòdia, aquesta és una estratègia conservacionista que presenta uns quants límits. En primer lloc, el caràcter voluntari dels acords suposa un obstacle per a una gestió conservacionista coherent a llarg termini. També cal tenir present la dificultat per assolir la complicitat necessària entre els actors del territori per consensuar un model de gestió conservacionista. Els propietaris reclamen incentius econòmics més grans per donar preferència a l'ús conservacionista per davant del productiu.

Les entitats de custòdia s'exclamen per la manca de fons públics per desenvolupar el servei ambiental que ofereixen per al conjunt de la societat, i de la poca difusió de la custòdia i baix reconeixement institucional. D'altra banda, l'elevat creixement del nombre d'entitats de custòdia pot generar problemes de coordinació entre si, i cada vegada es fa més evident la necessitat de delimitar la responsabilitat de les entitats de custòdia. En cas de mala gestió del territori, quina responsabilitat se'ls imputa?

En el cas concret de la CF es detecten uns quants límits: 
- Manquen entitats de custòdia que tinguin com a àmbit d'acció el conjunt de la conca hidrogràfica. L'actuació en trams concrets o en determinats rius no permet l'acció integral dels recursos hídrics a l'escala de conca hidrogràfica, que és l'àmbit geogràfic d'actuació que estableix la DMA.

- La gran diversitat d'actors implicats en la gestió dels rius dificulta el procés per arribar a acords de custòdia: pescadors, urbanistes, agricultors, empreses hidroelèctriques... A més, la seva sensibilitat sobre el riu és molt diversa, ja que mentre que alguns ja perceben els rius com a espais naturals, d'altres només hi veuen un recurs per explotar.

- Hi ha un elevat incompliment de la normativa sobre la protecció del medi fluvial. Per exemple, a l'hora de controlar les captacions, els abocaments, les explotacions clandestines... Sovint, els malfactors queden impunes per la dificultat per determinarne la responsabilitat. Aquesta realitat no ajuda a crear un ambient de confiança entre els actors.

- Definició poc clara del DPH, que dificulta la determinació dels propietaris implicats en l'acord de custòdia. A més, els rius no es limiten a l'espai delimitat pel domini públic, sinó que varien el traçat, per exemple en cas d'inundacions. Cal entendre, doncs, que l'àmbit d'actuació de les entitats de custòdia s'ha d'ampliar al conjunt de l'ecosistema fluvial, incloent també la zona de servitud i de policia, augmentant la complexitat jurídica ja que la titularitat d'aquests terrenys pot ser molt variada $\mathrm{i}$, a més, es superposa l'actuació de diverses administracions.

- Poca seguretat jurídica sobre el règim de concessions a causa de la indeterminació dels drets dels concessionaris, a l'abús d'aquests drets, al poc control administratiu i a la mancança del Registre d'Aigües perquè és incomplet o desactualitzat.

- Relació no sempre fàcil entre entitats i Administració: dificultat per intervenir en el DPH, lentitud per la tramitació dels permisos, desconfiança mútua, delimitació poc clara de les competències de cadascuna...

\section{CONSIDERACIONS FINALS}

Les actuals polítiques de gestió i conservació de la biodiversitat topen amb els límits de l'acció pública. La limitació de recursos humans, materials i econòmics ha obligat 
l'Administració a centrar els esforços en la protecció dels recursos naturals de més rellevància. Però part de la biodiversitat que s'ha de protegir es troba en finques privades no protegides.

La custòdia del territori es planteja com un mecanisme complementari a les polítiques públiques, ja que intervé, majoritàriament, en les finques privades incentivant la participació dels propietaris privats per conservar els valors naturals i culturals de les seves finques, i que fa responsables també els usuaris (població) dels espais naturals de la necessitat de gestionar i conservar aquests espais.

La custòdia planteja la necessitat del diàleg i del consens amb els diferents actors que gestionen el territori com a eix per a un desenvolupament sostenible. Tot i la voluntarietat dels acords, el treball pel respecte i la comprensió, crea uns lligams entre els actors que ajuda a consolidar la variable ambiental en els projectes. D'altra banda, en obrir la capacitat decisòria a més actors, permet crear polítiques amb més suport social, i ampliar el compromís de la societat davant el repte del desenvolupament sostenible.

Els mecanismes de custòdia s'apliquen en preferència als espais naturals sense protecció, tot i que també poden utilitzar-se en els espais protegits (per exemple, amb les inspeccions o les adopcions de trams de riu que proposa l'Associació Hàbitats a través del projecte Rius, que intervé en els espais de DPH).

Els acords tradicionals, basats en el dret privat, solen ser entre les entitats de custòdia i els propietaris privats de les finques. Però també es poden establir acords amb les administracions, per exemple a través dels convenis administratius plurianuals amb l'Estat que proposa la Llei 42/2007. En aquest treball plantegem que s'ampliïn els acords amb les administracions autònomes i les locals, i que s'augmenti la previsió de dos anys d'aquests convenis per donar més coherència a les actuacions de conservació dels espais naturals.

L'anàlisi dels acords de CF (custòdia del territori aplicada a les finques amb valors de medis aquàtics d'aigua dolça) realitzats a partir de les dades de l'últim inventari (octubre 2009) ens permet concloure que s'utilitzen fins a cinc tipus diferents d'acords, amb preferència pel contracte de custòdia del territori. Els acords "no escrits o verbals" ocupen el tercer lloc, i sorprenentment tenen una durada preferencial indefinida, i manifesten que la confiança basada en la voluntarietat entre els participants dels acords, també és font de seguretat jurídica. 
En total, gràcies als mecanismes de la $\mathrm{CF}$, s'ha aconseguit protegir 176 nous espais naturals que representen una extensió de 31.892, 26 ha, que 1'Administració per si sola no hauria pogut abastar. Majoritàriament, es tracta de finques de propietat privada, tot $\mathrm{i}$ que un $28 \%$ s'han realitzat en finques de propietat pública, i es posa de manifest el potencial de la custòdia del territori independentment de la titularitat de les finques.

El fort creixement del nombre d'acords de CF (de 12 a 176 en el període de 2003a 2009) mostra el potencial d'aquests mecanismes. Els actors del territori valoren les vies de diàleg i de consens per davant de la clàssica actuació imposant de l'Administració, a l'hora de dissenyar polítiques de gestió i conservació de la biodiversitat.

Actualment, ja hi ha 29 entitats amb acords de CF que mostren el compromís de les persones per treballar conjuntament amb l'Administració i els propietaris privats per consensuar polítiques sostenibles de gestió del territori.

D'altra banda, l'article analitza noves vies per activar els instruments de custòdia per superar l'acció clàssica de la intervenció en les finques, i protegir directament el recurs de l'aigua. Tot i que aquest recurs forma part del domini públic, l'Administració, com a ens gestor del recurs, podria cedir o arrendar la gestió de l'aigua a una entitat de custodia en el marc d'un conveni administratiu, expressament previst en alguna norma, sempre que es garantís l'interès general.

En el cas d'usos comuns especials, les entitats de custòdia poden intervenir per vetllar per la protecció de l'ecosistema fluvial en el moment que s'atorguin les autoritzacions administratives i les declaracions responsables.

Quant als usos privatius de l'aigua, sotmesos a concessions, les entitats de custòdia podrien intervenir per introduir criteris d'ús sostenible en relació, per exemple, per garantir els cabals de manteniment. També es planteja la possibilitat que les entitats sol·licitin concessions, per exemple, per gestionar l'ús ambiental de les aigües regenerades (recàrrega d'aqǘfers, recuperació de zones humides i manteniment de cabals) que segons les previsions del Programa de Reutilització d'Aigua de Catalunya (2009) se situaria en un 25\% el 2015.

En el cas d'aigües privades, la intervenció de les entitats de custodia podria contribuir a millorar la gestió dels recursos hídrics, complementant l'actuació de l'Administració per garantir un ús sostenible del recurs. En aquests casos, les entitats ampliarien el seu 
ventall d'acció, limitat a les aigües superficials, per treballar sobre el cicle hidrològic complet, ja que actuen sobre la fase atmosfèrica i subterrània de l'aigua.

El limitant principal per a la intervenció de les entitats en el recursos hídrics pròpiament, en el supòsit que les administracions en permetessin l'actuació, és la possibilitat que puguin veure alterat el seu rol habitual (protecció d'espais naturals privats), ja que poden convertir-se en agents de control de l'Administració.

Finalment, considerem que la custòdia del territori, i per extensió la $\mathrm{CF}$, no és una eina encara prou desplegada en la legislació autonòmica actual, i que planteja limitacions com la manca d'una actuació a l'escala de conca hidrogràfica, la complexitat per arribar a acords a causa de la diversitat d'actors i d'administracions competents o la definició poc clara del DPH, entre d'altres.

\section{BIBLIOGRAFIA}

AGUDO GONZÁLEZ, J. (coord.), El Derecho de aguas en clave europea, La Ley, Madrid, 2010.

ALCAIN MARTÍNEZ, E., El aprovechamiento privado del agua y su protección jurídica, Bosch, Barcelona, 1994.

ALVAREZ CARREÑO, S.M., HERNÁNDEZ LÓPEZ, S.M., "La Custodia del Territorio como instrumento complementario para la protección de espacios naturales", a Revista Catalana de Dret Ambiental, núm. 1 Vol. II, 2011.

ASSOCIACIÓ HÀBITATS, Manual d'adopció de rius. Eines per a la implicació social en la gestió dels espais fluvials, 2a ed., Associació Hàbitats, Barcelona, 2009.

BARREIRA, A. (coord.) [et al.], Estudio jurídico sobre la custodia del territorio. Plataforma de Custodia del Territorio de la Fundación Biodiversidad, 2010.

BLANCO LOZANO, C., Tratado de Derecho Penal Español, Volum II, Bosch, Barcelona, 2005, pàg. 230-238.

CARO-PATÓN CARMONA, I., "La Directiva Marco de aguas y su transposición al Derecho español: análisis jurídico general”, en Revista Aranzadi de Derecho Ambiental, núm. 9, 2006. 
CASADO CASADO, L., "Principales repercusiones de la directiva marco de aguas en el ordenamiento jurídico español”, a GONZÁLEZ-VARAS IBÁÑEZ, S. (coord.). Nuevo Derecho de Aguas, Civitas, Madrid, 2007.

EMBID IRUJO, Antonio., "Los nuevos Estatutos de Autonomia y el reparto de competencias sobre el agua y las obras hidráulicas entre el Estado y las Comunidades Autónomas”, en EMBID IRUJO, A. (coord.), Agua y territorio (Consideración especial de los Estatutos de Autonomia), Civitas, Madrid, 2007.

GÓMEZ GONZÁLEZ, JM.,'La Custodia del Territorio como instrumento social en la conservación del patrimonio natural”, en Revista Ecosostenible, núm. 16, 2006.

HÉRRAEZ VILAS, P., VICENS PEDRET, X., Derecho de aguas para los Entes locales, Bayer Hermanos, Barcelona, 2010.

GONZÁLEZ PASCUAL, M., "Las competencias estatutarias sobre aguas: las cuencas hidrográficas como criterio competencial (Comentario a las Sentencias 32/2011 y 30/2011 del Tribunal Contitucional)”, en Revista Aranzadi de derecho ambiental, núm. 20, 2011.

MORELL OCAÑA, L., "Las titularidades sobre aguas privadas", en Revista de Administración Pública, Madrid, núm. 154, 2001.

MORILLO-VELARDE PÉREZ, J.L., "La sentencia 30/2011, de 16 de marzo, una sentencia decepcionante", en Revista Andaluza de Administración Pública, núm 79, 2011.

MOREU BALLONGA, JL., Aguas públicas y aguas privadas, Bosch, Barcelona, 1996.

PALLARÈS SERRANO, A., "El recurs a la custòdia del territori i als acords voluntaris en l'àmbit del patrimoni natural i la biodiversitat", a Revista catalana de dret públic, núm. 41, 2010.

RAZQUIN LIZARRAGA, J.A., "Las competencias autonómicas en materia de aguas (A propósito de las SSTC 30/2011 y 32/2011)”, en Revista Aranzadi Doctrinal, núm. 3, 2011.

WWF (2007), “Guía para el diseño y ejecución de programas de voluntariado ambiental en ríos y riberas". [Recuperat el 15 de juny de 2011 de: < http://www.marm.gob.es/es/agua/publicaciones/Guia_para_el_disenio_y_ejecucion_de_progra mas_de_voluntariado_tcm7-10387.pdf $>$ ]. 


\section{Documents de l'XCT}

ASENSIO, N., CORTINA, A., PIETX, J., COLlADO, H., Opcions de custòdia del territori per a finques privades. Una guia per a la propietat, 2a edició (revisada per Hernan Collado), FTP-OSCC, XCT, Vic, 2005.

ASENSIO, N.; COLLADO, H., Protocol de seguiment $i$ avaluació d'acords per a entitats de custòdia del territori. Document ocasional de la Xarxa de Custòdia del Territori, 16, Xarxa de Custòdia del Territori ,Vic, 2007.

BASORA, X.; GORDI, J.; SABATÉ, X.; VICENTE, E., Oportunitats per la custòdia del territori als municipis. Guia pràctica per a ajuntaments $i$ entitats local, FTP-OSCC, XCT, Barcelona, 2005.

BASORA, X.; SABATÉ, X., Custodia de territorio en la práctica. Manual de introducción a una nueva estrategia participativa de conservación de la naturaleza y el paisaje, FTP-OSCC, XCT, Barcelona, 2006.

BRONCANO, M.J.; COMAS, E.; PIETX, J. (2007, octubre). III Inventari d'Acords i Entitats de Custòdia del Territori a Catalunya, les illes Balears i Andorra. Informes de la Xarxa de Custòdia del Territori, 17. [Recuperat el 22/11/2009, de : $<$ http://www.xct.cat/ca/cdr/informes.html $>$ ].

MORENO, R.; PIETX, J. (2003, novembre). I Inventari d'Acords i Entitats de Custòdia del Territori a Catalunya, les illes Balears i Andorra. Informes de la Xarxa de Custòdia del Territori, 17. [Recuperat el 22/11/2009, de : $<$ http://www.xct.cat/ca/cdr/informes.html $>$ ].

OLliCH, M.; PARRA, C., Seminari empresa i Territori. Conclusions, Document ocasional de la Xarxa de Custòdia del Territori núm. 16, XCT, Vic, 2006.

PUIG, M.; MASÓ, M. (2009a). IV inventari d'Acords i Entitats de Custòdia del Territori a Catalunya, les illes Balears i Andorra. Informes de la Xarxa de Custòdia del Territori, 17. [Recuperat el 22/11/2009, de : $<$ http://www.xct.cat/ca/cdt/inventari.html $>$ ].

PUIG, M.; MASÓ, M. (2009b), Base de Dades del IV inventari d'Acords i Entitats de Custòdia del Territori a Catalunya, les illes Balears i Andorra. Informes de la Xarxa de Custòdia del Territori, 17. [Recuperat el 22/11/2009, de : $<\underline{\text { http://www.xct.cat/ca/cdt/inventari.html }>\text { ]. }}$. 
SURINYAC, L.; MORENO, R. (2005, novembre). II Inventari d'Acords i Entitats de Custòdia del Territori a Catalunya, les illes Balears i Andorra. Informes de la Xarxa de Custòdia del Territori, 17. [Recuperat el 22/11/2009, de: $<$ http://www.xct.cat/ca/cdr/informes.html $>$ ].

XARXA DE CUSTÒDIA DEL TERRITORI, MEDIA RESPONSABLE (2010). Guia de bones pràctiques de RSE i Custòdia del Territori. [Recuperat el 9/6/2011 de $<$ http://www.xct.cat/mm/GUIA\%20BONES\%20PRACTIQUES_definitiva.pdf $>$ ].

\section{Documents de l'ACA}

GODÉ, Ll. (direcció), La gestió i recuperació de la vegetació de ribera, Agència Catalana de l'Aigua, Barcelona, 2008.

SABATÉ, X.; BASORA, X.; ROMERO-LENGUA, J., Confluint en la cura de l'aigua. Reflexions sobre l'encaix entre la custòdia del territori i la Directiva marc de l'aigua a Catalunya, Agència Catalana de l'Aigua, Barcelona, 2008.

AGÈNCIA CATALANA DE L'AIGUA. (2009). Programa de Reutilització d'Aigua a Catalunya. [Recuperat el 15/011/2009 de: $<$ http://acaweb.gencat.cat/aca/documents/ca/planificacio/reutilitzacio/PRAC_V_3_1.pdf $>$ ].

AGÈnCiA CATALANA DE L'AIGUA. (2005). Pla Sectorial de cabals de manteniment de les conques internes de Catalunya .Memòria Tècnica. [Recuperat el 15/10/2009 de: $\quad<\quad$ http://acaweb.gencat.cat/aca/documents/ca/planificacio/cabals/pla_sectorial_cabals_de_mantenim ent_cic.pdf $>$ ] 